\title{
Anticorruption as Transnational Law: \\ The Foreign Corrupt Practices Act, PRC Law, and Party Rules in China
}

\author{
Matthew S. Erie \\ Associate Professor of Modern Chinese Studies \\ University of Oxford China Centre \\ Dickson Poon Building \\ Canterbury Road \\ Oxford UK OX26LU \\ matthew.erie@orinst.ox.ac.uk \\ Forthcoming in the American Journal of Comparative Law. \\ Please do not cite without permission of the author.
}

\begin{abstract}
Corruption has been linked to urgent transnational problems, including, inter alia, market uncertainties, the undermining of democracy, economic disparity, religious extremism, and authoritarianism. As corruption is a global problem, it requires coordination across states' anticorruption laws. Anticorruption thus provides grounds to reassess the promise and limits of transnational law. This article examines the operation of anticorruption as transnational law across the corporate governance regimes of the United States and China, the world's two largest economies. As opposed to perceptions that Washington and Beijing are engaged in a zero-sum game, anticorruption is a policy concern against which both states rally. Interregulatory coordination is far from a frictionless process, however. Cross-border lawyers working on both sides of the Pacific engaged in anticorruption law are a type of transnational community and highlight these tensions. Lawyers apply standards in the 1977 U.S. Foreign Corrupt Practices Act, the People's Republic of China antibribery laws, and internal Chinese Communist Party rules to ensure their clients comply with multiple regimes. Ethnographic data shows that lawyers assess different regulatory environments, in this case, one of extraterritorial jurisdiction and the other characterized by a political campaign, in the course of advising multinational companies. The article argues that lawyers' roles are a lynchpin of these overlapping systems of compliance as their work operates to discipline corporations in China; nonetheless, lawyers' position in the global legal market impacts what they deem to be "corrupt" and which rules apply. A focus on cross-border lawyers as transnational communities thus marries legal analysis with a contextual grounding in lawyers' work, an approach that has merit for the study of comparative law more generally. The article finds that given market pressures, in the area of anticorruption, trends show a preference for "bicultural lawyers," those who are both embedded within transnational communities and respond to demands in the global market.
\end{abstract}


Keywords: FCPA, anticorruption, compliance, ethnography, transnational law, U.S-China relations

\section{Acknowledgements}

This Article has benefitted from presentations at Harvard University, Princeton University, University of Pennsylvania, New York University's U.S.-Asia Law Institute, and the 2016 American Anthropological Association meeting. The author would like to thank Sally Engle Merry, Jerome Cohen, Sharon Hom, Sida Liu, Kevin Davis, Benjamin van Rooij, Gregory Shaffer, Loren Goldman, Diana Pilipenko, and Kyle Jaros for their comments on drafts. All mistakes are the author's. 
If you're too clean in the system, people will be afraid of you. They think you don't play by the rules. They fear you might report on them. And you won't be able to function.

-A Chinese official to a securities regulator in 1999

It's better to operate in a clean environment.

-A Chinese partner in a private equity firm in 2016

\section{Introduction}

"Massage" (anmo), "prostitute" (xiaojie), and "golf" (gao'erfuqiu)—these were keywords of an internal investigation in which I participated in 2012, while engaged in the legal practice of the Foreign Corrupt Practices Act (FCPA, see Table 1 for all abbreviations used in this Article) $)^{1}$ at an international law firm. The FCPA is a U.S. statute that imposes criminal and civil liability on individuals and corporate entities that bribe officials abroad. ${ }^{2}$ I assisted in conducting internal investigations of clients, major multinational corporations (MNCs), to preempt investigations by the Department of Justice (DOJ) or Securities Exchange Commission (SEC). In the case in 2012, a whistleblower alerted the companies' in-house counsel of bribery by an employee in the People's Republic of China (PRC). Along with several other associates, based in New York, Washington, D.C., and Beijing, using e-discovery software, I poured through thousands of Chinese-language electronic files to identify evidence of the wrongdoing, including the three keywords identified by a senior associate. The relevant language of the FCPA to determine what qualifies as an unfair benefit is "anything of value"-a tremendously ecumenical category. ${ }^{3}$ Upon discovering one of these terms in a document (e.g., an e-mail), I would flag it in the data room for the senior associate to review. The

\footnotetext{
${ }^{1}$ Pub. L. No. 95-213, 91 Stat. 1494 (1977).

${ }^{2}$ See 15 U.S.C. $\S \S 78 \mathrm{dd}-1$ to $\S \S 78 \mathrm{ff}(2012)$.

${ }^{3}$ See section 30A(a) of the Securities Exchange Act of 1934, Pub. L. No. 73-291, 48 Stat. 881 (Exchange Act); 15 U.S.C. $\S \S 78 d d-1(a), 78 d d-2(a), 78 d d-3(a)$.
} 
senior associate would further refine the search criteria in the process of gathering evidence.

[insert Table 1 here]

Five years later, the cars of PRC officials — which have distinct license platescannot be seen at massage parlors for fear of the officials being arrested; the karaoke bars with prostitutes have been closed; and the Chinese Communist Party (CCP or Party) has prohibited members from joining golf clubs as of 2015. These are just some of the changes wrought by President Xi Jinping's epochal anticorruption campaign, which he started in 2012 when he assumed the leadership of the government and of the CCP. ${ }^{4}$ PRC state law, as well as a body of internal CCP rules, has effected a culture shift at the intersection between the public and private sectors in China. ${ }^{5}$ As with the epigraphs that start this Article, the obsolescence of my keywords illustrates the rapidity with which the referents for normative categories (i.e., "corruption”) and legal language (e.g., "anything of value") change. Whereas FCPA lawyers conducting internal investigations today may continue to search for such terms, they may equally look for evidence of offshore accounts, third parties, slush funds, and other sophisticated forms of corruption.

\footnotetext{
${ }^{4}$ Macabe Keliher \& Hsinchao Wu, Corruption, Anticorruption, and the Transformation of Political Culture in Contemporary China, 75 J. AsIAN STUD. 5 (2016); Ling Li, The Rise of the Discipline and Inspection Commission, 1927-2012: Anticorruption Investigation and Decision-Making in the Chinese Communist Party, 42 MOD. CHINA 447 (2016).

${ }^{5}$ Chen Lin et al., Anti-Corruption Reforms and Shareholder Valuations: Event Study Evidence from China, NAT'L Bur. ECON. ReSEArCh Working PAPER No. 22001 (2016); Hualing Fu, China's Striking AntiCorruption Adventure: A Political Journey Towards the Rule of Law?, in THE BEIJING CONSENSUS? How China Has Changed the WeStern Ideas of LAW ANd ECONOMic DeVelopment ch. 10 (Weitseng Chen ed. 2017); Hualing Fu, Wielding the Sword: President Xi's New Anti-Corruption Campaign, in GreED, Corruption, AND the Modern STATE: EsSays in Political EConomy 134 (Susan Rose-Ackerman \& Paul Lagunes eds., 2015); John M. Griffin et al., Is the Chinese Anti-Corruption Campaign Effective? (forthcoming), https://papers.ssrn.com/sol3/papers.cfm?abstract_id=2779429.
} 
Legal practices of anticorruption, domestic and foreign, respond to each other. Cross-border lawyers who apply laws of different jurisdictions adapt the elements of foreign law to local contexts, just as the understanding of what constitutes "corruption" locally informs corporate governance. The practices of the FCPA and PRC anticorruption campaign demonstrate how multiple regulatory regimes coexist in transnational law. ${ }^{6}$ On the one hand, the FCPA is a long-arm statute conferring extraterritorial jurisdiction upon the DOJ and SEC to punish those who pay bribes to foreign officials, and is designed to bolster corporate governance abroad. ${ }^{7}$ On the other hand, the CCP's anticorruption campaign is a domestic political movement responding to a crisis in the Party's legitimacy by cleaning up official corruption, government officials or Party members (often the same person) receiving bribes, sometimes from foreign businesses. ${ }^{8}$ By most accounts, the campaign is working. ${ }^{9}$ While prosecutions in China for corruption, as well

\footnotetext{
${ }^{6}$ By "transnational law," I mean law that regulates actions that transcend national frontiers and whose primary sources and actors are private, and involved in transnational relations, as opposed to international law, which acts on states primarily through treaties. See Roger Cotterrell, What Is Transnational Law?, 37 LAW \& Soc. Inquiry 501 (2012); Philip C. Jessup, Transnational laW (1956). See also Christiane C. Wendehorst, State as Foundation of Private Law Reasoning, 56 AM. J. CoMP. L. 567 (2008); Peer Zumbansen, Law After the Welfare State: Formalism, Functionalism, and the Ironic Turn of Reflexive Law, 56 AM. J. COMP. L. 769 (2008).

${ }^{7}$ U.S. Dep'T OF Justice \& SeC. AND EXCh. COMm'n, A Resource Guide to the U.S. Foreign Corrupt PRACTICES ACT (Nov. 14, 2012), https://www.justice.gov/sites/default/files/criminalfraud/legacy/2015/01/16/guide.pdf.

${ }^{8}$ See Wei Ceng (曾伟), Xi Jinping Tan Fanfu: Youfu Bifan Juebu “Yanghuweihuan” (习近平谈反腐：有 腐必反决不“养虎为患”) [Xi Jinping Discusses Anti-Corruption: If There Is Corruption, Then We Must Absolutely Not "Nurture the Tiger So As To Bring About Disaster"], RENMIN WANG (人民网) [People's Net] (July 30, 2014), http://politics.people.com.cn/n/2014/0730/c1001-25372496.html (providing a chronology of President Xi Jingping's statements about the goals of the anticorruption movement from 2012 to 2014.)

${ }^{9}$ See Melanie Manion, Taking China's Anticorruption Campaign Seriously, 4 ECon. \& POL. STUd. 3 (2016); Shi Yao (姚诗), Zhongguo Fanfubai Falü Zhiding he Shishi de Jinzhan, Wenti yu Zhengce: Jiyu UNCAC de Pinggu (中国反腐败法律制定和实施的进展, 问题与对策: 基于 UNCAC 的评估) [The Achievements, Deficiencies and Countermeasures of the Legislation and Enforcement of Anticorruption Law in China: An Evaluation Based on the UN Convention Against Corruption], 15 GuANGZHOU DAXUE XUEBAO (SheHUI KEXUEBAN) (广州大学学报（社会科学版） ) [J. GUANGZHOU U. (SOC. SCI. ED.)] 5 (2016); Yongguan Zhai (翟永冠) et al., 2016 Nian Zhongguo Fanfu Bada Kandian (2016 年中国反腐八大 看点) [Eight Main Points of China's Anticorruption Movement in 2016], XINHUA (新华) [New China]
} 
as those in the United States for FCPA violations in China, have increased, the state has also instituted extralegal mechanisms, including information campaigns and regulatory measures. Contrary to the literature on white-collar crime, that suggests that general deterrence may not reduce corrupt acts, ${ }^{10}$ this combination appears to be changing corporate behavior. These two anticorruption regimes have different origins but converge in the offices of lawyers at both sides of the Pacific, all of whom practice the FCPA. ${ }^{11}$

The central claim of this Article is that to understand how transnational governance operates, the analysis must be attuned to the practices of those communities of lawyers who engage in such work; centrally, cross-border lawyers engage in anticorruption compliance, a form of "self-discipline," which is embedded within legal, regulatory, and ethical frameworks (e.g., bilateral United States-China legal enforcement, PRC commercial administration, Party campaigns, etc.), and which supports those frameworks. ${ }^{12}$ More generally, the account of the interaction between the FCPA and the PRC anticorruption movement has lessons for the study of comparative law, specifically the understanding of how transnational law operates. Over the past decade, scholars have observed the emergence of transnational governance of global problems, whether environmental, security and antiterrorism, corporate governance, or corruption, through

(Mar. 15, 2016), http://fanfu.people.com.cn/n1/2016/0315/c64371-28199222.html (listing accomplishments of the anticorruption campaign to date).

${ }^{10}$ See Natalie Schell-Busey et al., What Works? A Systematic Review of Corporate Crime Deterrence, 15 Criminology \& Public Policy 387 (2016); Sally S. Simpson et al., Corporate Crime Deterrence: A Systematic Review, 4 CAMPBell Systematic ReVs. 1 (2014).

${ }^{11}$ In addition to the FCPA and PRC anticorruption laws, cross-border lawyers working on China-related deals may analyze the anticorruption statutes of other jurisdictions, chiefly the UK Bribery Act 2010, c. 23.

${ }^{12}$ See John Braithwaite \& Peter Drahos, Global Business Regulation (2000); Christine Parker \& Vibeke Nielsen, The Challenge of Empirical Research on Business Compliance in Regulatory Capitalism, 5 ANN. REV. LAW \& SOC. SCI. 48 (2009). 
the increased role of private actors, including firms and professionals. ${ }^{13}$ Hybrid private/public partnerships are central to these novel forms of regulating problems that cross borders. ${ }^{14}$ These partnerships form transnational communities that operate across jurisdictions to make rules or standards to address a given problem. ${ }^{15}$ The study of lawyers practicing the FCPA, in particular, shows how market preferences within those communities influence the standards used to define a transnational problem - in this case, corruption.

Transnational law has been described as a "transnational legal order,", "regime," $" 17$ or "global legal pluralism." $" 18$ While these theories have advanced the study of transnational law qua structure, and because they explain, in part, cross-border anticorruption law, a focus on structure requires the counterbalance of agencyspecifically that of lawyers. ${ }^{19}$ The concept of "transnational community" suggests that

\footnotetext{
${ }^{13}$ Scott Mann et Al., Transnational Governance: Emerging Models of Global Legal Regulation (2016); Michelle SANSOn, InTERnational LAW AND Global Governance (2008); ANNEMarie Slaughter, A NeW World Order (2005).

${ }^{14}$ Walter Mattli \& Tim Büthe, Global Private Governance: Lessons from a National Model of Setting Standards in Accounting, 68 LAW \& CONTEMP. ProBS. 225 (2005); David M. Trubek \& Louise G. Trubek, New Governance and Legal Regulation: Complementarity, Rivalry, and Transformation, 13 Colum. J. EuR. L. 540 (2006); Peer Zumbansen, Neither 'Public' nor 'Private', 'National' nor 'International': Transnational Corporate Governance from a Legal Pluralist Perspective, 38 J. LAW \& SoC. 50 (2011).

${ }^{15}$ Errol Meidinger, The Administrative Law of Global Private-Public Regulation: the Case of Forestry, 17 EUR. J. INT'L LAW 47 (2006); Alan J. Richardson \& Burkard Eberlein, Legitimating Transnational Standard-Setting: The Case of the International Accounting Standards Board, 98 J. Bus. ETHICs 217 (2011).

${ }^{16}$ Terence C. Halliday \& Gregory Shaffer, TRANSNATIONAL LEgAL ORDERS (2014); Gregory C. Shaffer, Transnational Legal Ordering AND State Change (2012).

${ }^{17}$ Gunther Teubner \& Peter Korth, Two Kinds of Legal Pluralism: Collision of Transnational Regimes in the Double Fragmentation of World Society, in REGIME INTERACTION IN INTERNATIONAL LAW: FACING FRAGMENTATION 23 (Margret Young ed., 2012).

${ }^{18}$ Paul SChiff Berman, Global Legal PluRAlism: A JuRisprudence of LAW BEyond Borders (2012); Ralf Michaels, The Re-State-ment of Non-State Law: The State, Choice of Law, and the Challenge from Global Legal Pluralism, 51 WAYNE L. REV. 1209 (2005).

${ }^{19}$ The sociologist Pierre Bourdieu famously sought to reconcile objectivist and subjectivist orientations toward law (or, structure and agency). See Pierre Bourdieu, The Force of Law: Toward a Sociology of the Juridical Field, 38 HASTINGS L.J. 805, 807 (1987) (arguing one must look to "internal politics of the profession," the codes of "the field," which have a determining power).
} 
members share cultures or interests. ${ }^{20}$ Whereas the sets of professionals who work on problems of cross-border corruption, including lawyers and regulators, share, generally, the same objective and exhibit similarities in professional skill sets, their relationships both within and across jurisdictions can just as often be antagonistic as collaborative. Studies to date have insufficiently paid attention to the role of the market in not just forming the transnational community but fomenting competition within it. I apply "transnational community" loosely to those lawyers ${ }^{21}$ who engage in anticorruption regulatory work for clients with business in China while recognizing that alignment of interests are not exclusive of competing interests and that agency operates within a set of professional and marketized structures. ${ }^{22}$

The remainder of this Article is divided into the following sections. The first describes corruption as a global problem. The second situates anticorruption law in the context of cross-border compliance. The third discusses the methodology and data used to understand how lawyers practice compliance across multiple regulatory regimes. The fourth explains the different regulatory approaches of the United States and the PRC. The fifth provides ethnographic data on the capacity of lawyers to analyze and apply the different legal standards between the anticorruption regimes, specifically through internal investigations. An ethnographic approach shows that the lawyers' positions in the transnational community bear on how they approach the standards with which to assess corporate exposure to FCPA liability. The conclusion underscores the importance of

\footnotetext{
${ }^{20}$ Marie-Laure Djelic \& Sigrid Quack, Transnational Communities and Governance, in TRANSNATIONAL COMmunities: Shaping Global Economic Governance 3 (Marie-Laure Djelic \& Sigrid Quack eds., 2010).

${ }^{21}$ Although this Article focuses on lawyers, I recognize cross-border anticorruption involves a number of actors, including compliance officers, auditors, government officials, and security and risk analysts, among others.

${ }^{22}$ See Pierre Bourdieu, The Logic of Practice 41 (Richard Nice trans., 1990) (proposing "habitus" to analyze agency embedded within "structured, structuring dispositions").
} 
understanding transnational communities of lawyers for the study of transnational law more broadly.

\section{Corruption as a Global Problem}

Despite recent economic and political movements from the U.K.'s referendum to leave the European Union to the rise of nationalism in the United States and Europe, all of which suggest a turn against globalization, global problems are on the rise. Indeed, populist reactions give credence to the perceived threat of globalization. These problems include, inter alia, environmental degradation, religious fundamentalism, civil wars and forced migration, and economic inequality. Sarah Chayes, former special advisor to the Chairman of the Joint Chiefs of Staffs, has linked all of these symptoms of globalization to corruption. ${ }^{23}$ Chayes is worried most about kleptocracies, and yet corruption is a problem in a number of settings. ${ }^{24}$ From capital flight from failed states to the externalities of international business, ${ }^{25}$ corruption is a cross-border problem that exceeds the policing capacity of any one government.

Classical definitions hold corruption to be the abuse of public office for private gain. ${ }^{26}$ Susan Rose-Ackerman identifies the poor management of self-interest,

\footnotetext{
${ }^{23}$ Sarah Chayes, Thieves of States: Why Corruption Threatens Global Security (2015).

${ }^{24}$ Daniel A. Bell, The China Model: Political Meritocracy and the Limits of Democracy 112 16 (2015); Philip M. Nichols, The Psychic Costs of Violating Corruption Laws, 45 VAND. J. TRanSNaT'L L. 145 (2012); Hilton L. RoOt, SMAll Countries, Big LeSSONS: GovernanCE AND THE RiSE OF EAST ASIA (1996); Bo Rothstein, Anti-Corruption: A Big-Bang Theory, 18 REV. InT'L POL. ECON. 228 (2011). ${ }^{25}$ Clare Fletcher \& Daniela Herrmann, The INTERNATIONALiSATION OF CORRUPTION: SCALE, IMPACT AND COUNTERMEASURES (2012); SHARON EICHER, CORRUPTION IN INTERNATIONAL BUSINESS: The Challenge of Cultural and Legal Diversity (2009).

${ }^{26}$ Joseph S. Nye, Corruption and Political Development: A Cost-Benefit Analysis, 61 AM. PoL. SCI. ReV. 417, 419 (1967) (defining corruption as "behavior which deviates from the formal duties of a public role because of private-regarding (personal, close family, private clique) pecuniary or status gains; or violates rules against the exercise of certain private-regarding influence"); ARNOLD HEIDENHEIMER, POLITICAL CORRUPTION: READINGS IN COMPARATIVE ANALYSIS (1970).
} 
particularly in developing economies, as the root of corruption. ${ }^{27}$ Indices that measure perceptions of corruption per country have become an important industry, in part driven by investment aims targeting developing countries. The most well known among these is the Corruption Perception Index (CPI) by Transparency International. The CPI does not measure actual corruption, but is rather based on proxies, and has been widely criticized. ${ }^{28}$ Nevertheless, some lawyers who practice the FCPA use the CPI to advise clients on the question of which countries to invest in. ${ }^{29}$ Given the clandestine nature of corruption, approximations of actual corrupt practices in countries have been much more difficult to gather. As a result of this measurement problem, anticorruption strategies often rely on quantitative measures such as the CPI. ${ }^{30}$

There is a close relationship between the ways in which corruption is measured and its governance. ${ }^{31}$ Law endeavors to set protocols for behavior, for example, between what is a permissible "grease payment" versus an illegal bribe. More specifically, these protocols can take the form of bright line rules, such as maximum monetary thresholds, or general categories of standards (e.g., "anything of value"). To be even more precise, the difference between rules and standards is law that is determined ex ante (i.e., someone subject to a rule knows its content before engaging in behavior) versus ex post (i.e., someone is put on notice as to a general standard, and a judge or lawyer determines

\footnotetext{
${ }^{27}$ Susan Rose-ACKERMan, CORRUPtion AND GOVERnMENT: CAUSES, CONSEQUENCES, AND REFORM 2 (1999).

${ }^{28}$ Staffan Andersoon \& Paul M. Heywood, The Politics of Perception: Use and Abuse of Transparency International's Approach to Measuring Corruption, 57 POL. STUD. REV. 746 (2009); Paul M. Heywood \& Jonathan Rose, "Close but No Cigar": The Measurement of Corruption, 34 J. PuB. POL. 507 (2014).

${ }^{29}$ Stuart Vincent Campbell, Perception Is Not Reality: The FCPA, Brazil, and the Mismeasurement of Corruption, 22 MinN. J. INT'L L. 247 (2013).

${ }^{30}$ Petter Langseth, Measuring Corruption, in MEASURING CORRUPTION 7, 14 (Charles Sampford et al. eds., 2006).

${ }^{31}$ See Kevin Davis Et AL., Governance By IndiCATORS: Global Power Through QuANTIFICATION And Rankings (2012); SAlly Engle Merry et AL., The Quiet Power of IndicAtors: MEASURING Governance, Corruption, and Rule of LaW (2015); Sally Engle Merry, The Seduction of QuANTificATiOn: MEASURing Human Rights, GENDER Violence, AND SEX TrafFicking (2016).
} 
whether there has been a violation of that standard after the fact). ${ }^{32}$ Anticorruption regimes, which entail not just national law and policy, but also the corporate policies that incorporate such law and policy into best business practice, involve both rules and standards. The crucial question of defining corruption, at least for the FCPA, however, takes the form of a standard.

Law’s approach to governing corrupt behavior differs from ethnographic treatments of corruption. Whereas law looks to intent, evidence, and wrongdoing, ethnography points to "social strategies, cultural logics, and moral economies that assign values" to acts that differ from those of the state. ${ }^{33}$ It is possible, from an ethnographic point of view, to perceive an act in ways other than law's categorization as a "bribe." Further, cultural traditions may not be the sole source of such behavior, ${ }^{34}$ but rather social and commercial contexts that interact dynamically with forms of global capitalism. This is particularly so in postsocialist countries. ${ }^{35}$

As a lawyer and an anthropologist, I recognize the tension between these two approaches to corruption. Nowhere are such differences more apparent than in the case of China. The anthropological literature has long noted that routines of gifting, banqueting, hosting, and other forms of material and symbolic exchange are the glue of guanxi (social

\footnotetext{
${ }^{32}$ See Louis Kaplow, Rules Versus Standards: An Economic Analysis, 42 DuKE L.J. 557 (1992); Russell B. Korobkin, Behavior Analysis and Legal Form: Rules vs. Standards Revisited, 79 OR. L. REV. 23 (2000).

${ }^{33}$ DANiEl Jordan SMith, A CULTURE of CORRUPTION: EVERydAy DECEPTION AND POPULAR DisCONTENT in Nigeria 11 (2007); see also SteVen Pierce, Moral ECONOMIES Of CORRUPTION: STATE Formation AND POLITICAL CUlTURE IN Nigeria (2016).

${ }^{34}$ Scholars have found in cultural traditions fertile ground for critique of corruption. See, e.g., Toke S. Aidt, The Causes of Corruption, CESIFO DiCE REP. 15, 17-18 (2011); Daniel Treisman, The Causes of Corruption: A Cross-National Study, 76 J. PUB. ECON. 399, 437 (2000).

${ }^{35}$ Smoki Musaraj, Tales from Albarado: The Materiality of Pyramid Schemes in Postsocialist Albanai, 26 CUlT. ANTH. 84 (2011); Kim Lane Scheppele, The Inevitable Corruption of Transition, 14 CONN. J. INT'L L. 509 (1999); Katharine Verdery, What Was Socialism, AND What COMES NeXt? 20-28 (1996).
} 
connections). ${ }^{36}$ From the legal standpoint, guanxi, with its connotations of nepotism, clientelism, particularistic ties, and male chauvinism, has been particularly singled out as an obstacle to the "rule of law." such concerns. In the first year of its existence in 1995, the CPI ranked China second to Indonesia as the country perceived as most corrupt in the world. ${ }^{38}$ As of 2015 , the CPI ranked China 83 out of 168 countries, putting it in the middle of the pack. ${ }^{39}$ The perception of China as corrupt or moderately corrupt has not necessarily hindered foreign direct investment in the country. ${ }^{40}$ Foreign business has had mixed experiences in China, with a common denominator, from the 1980s at the start of economic reforms, being a "when in Rome" mentality. ${ }^{41}$ While skeptics see that such behavior can lead to a race to

\footnotetext{
${ }^{36}$ Andrew Kipnis, Practice of Guanxi Production and Practices of Ganqing Avoidance, in SOCIAL Connections in China: Institutions, Culture, And the Changing NATURE of GuAnXi 21 (Thomas Gold et al. eds., 2002); John Osburg, AnXious Wealth: Money And Morality Among China's New RICH (2013); Alan Smart \& Carolyn L. Hsu, Corruption or Social Capital? Tact and the Performance of Guanxi in Market Socialist China, in Corruption AND THE SECRET OF LAW: A LEGAL ANTHROPOLOGICAL PERSPECTIVE 167 (Monique Nuijten \& Gerhard Anders eds., 2013); MAYFAIR MEI-HUI YANG, GIFTS, FAVORS, AND BANQUETS: THE ART OF SOCIAL RELATIONSHIPS IN CHINA (1994).

${ }^{37}$ One of the most trenchant criticisms of guanxi was from the Chinese sociologist Fei Xiaotong. See Xiaotong Fei, From the Soil: The Foundations of Chinese Society 43 (Gary G. Hamilton \& Wang Zheng trans., 1992). See also Randall PeErenboom, ChinA’s Long March Toward Rule of Law 19, 470, 496 (2002); Eric W. Orts, The Rule of Law in China, 34 VAND. J. TrANSN'L L. 10 (2001).

38 See 1995 TI Corruption Index, TRANSPARENCY INT'L (1995), http://www.transparency.org/files/content/tool/1995_CPI_EN.pdf.

39 See Corruption Perception Index TrANSPARENCY INT'L_ (2015), https://www.transparency.org/cpi2015/.

40 See Wayne M. Morrison, ChinA’s ECONOMic Rise: History, Trends, Challenges, And IMPLICATIONS FOR THE UNITED STATES 14 (2015) (citing U.N. figures that from 1985 to 2014, China's foreign direct investment figures grew from $\$ 2$ billion to $\$ 128$ billion).

${ }^{41}$ There is a cottage industry for chief executive officers (CEOs) and managers of "how to do business in China" replete with tragic cases of privileging guanxi over law PRC law and policy over corporate ethics. See Christopher Torrens, Doing Business in ChinA: A Guide to the Risks AND RewARds (2010); Tim Ambler et al., Doing Business in China (2009); Tim Clissold, Mr. China (2009). Certainly, not all foreign companies in China prioritize market access over ethical responsibility. See BEN W. HEINEMAN, JR., The Inside Counsel Revolution: Resolving the PARTner-GuARdian Tension (2016) (describing conflicts between global corporate ethics and Chinese Internet censorship as the general counsel for General Electric). One PRC lawyer I spoke to approached this issue historically, calling the time after Deng Xiaoping's tour of southern China in 1992 a "Wild West" period, a period that, by the 2000s, was over. After the global economic recession in 2008, stricter corporate governance in the U.S. and China's own anticorruption drive, caused businesses to conform to a new set of rules and heightened requirements for transparency and accountability.
} 
the bottom in corporate governance, ${ }^{42}$ others see guanxi as playing a stabilizing role in the developing legal system. ${ }^{43}$ Lawyers who advise clients on FCPA matters are keenly aware of cultural expectations for gifting in China. How they reconcile such cultural norms with the regulatory environments under U.S. and PRC laws requires attention to the everyday work of compliance. To understand this work, I situate anticorruption law in the broader field of compliance.

\section{From Law to Compliance}

The work of cross-border lawyers is crucial to the practice of anticorruption law as a type of transnational governance because the FCPA operates principally through compliance. "Compliance" is a term with many meanings as applied to law, including international law ${ }^{44}$ and domestic law. ${ }^{45}$ Most generically, all law induces compliance in that compliance is the way in which social behavior conforms to (legal) norms and, in

\footnotetext{
${ }^{42}$ See Chris Devonshire-Ellis, It's Not About Guanxi. It's About Your Business Model and Due Diligence, DEZAN SHIRA \& ASSOCIATES (Oct. 8, 2010), http://www.china-briefing.com/news/2010/10/08/its-notabout-guanxi-its-about-your-business-model-and-due-diligence.html.

${ }^{43}$ See Antara Haldar \& Joseph E. Stiglitz, Analyzing Legal Formality and Informality: Lessons from Land Titling and Microfinancing Programs, in LAW AND ECONOMICS WITH CHINESE CHARACTERISTICS: Institutions for Promoting DeVelopment in the Twenty-First Century 112, 132 (David Kennedy \& Joseph E. Stiglitz eds., 2013); Pitman B. Potter, Guanxi and the PRC Legal System: From Contradiction to Complementarity, in Social ConNeCtions in China: Institutions, Culture, AND the Changing NAtURE OF GUANXI 179 (Thomas Gold et al. eds., 2002); Mary Szto, Chinese Gift-Giving, Anti-Corruption Law, and the Rule of Law and Virtue, 39 FORDHAM INT'L L.J. 591 (2016).

${ }^{44}$ For international law, the key question of compliance is why states conform their behaviors to international standards. See, e.g., Benedict Kingsbury, The Concept of Compliance as a Function of Competing Conceptions of International Law, 19 MiCH. J. InT'L L. 345 (1998); Andrew T. Guzman, A Compliance-Based Theory of International Law, 90 CAL. L. REV. 1823 (2002); Kal Raustiala \& AnneMarie Slaughter, International Law, International Relations and Compliance, in THE HANDBOOK OF INTERNATIONAL RELATIONS 538 (Walter Carlsnaes et al. eds., 2002).

${ }^{45}$ Compliance applies to a wide array of domestic legal areas, including, inter alia, corporate law, criminal law, antidiscrimination law, environmental law, financial regulation, land law, intellectual property, antitrust law, and tax law. See Geoffrey P. Miller, The Law of Governance, RisK Management, AND COMPLIANCE (2014).
} 
turn, shapes those norms. ${ }^{46}$ In a narrower sense, under what is called, in certain industries, regulatory compliance or compliance management, MNCs develop internal policies and programs that align their operations with relevant laws and regulations at the local, national, or international levels; alongside compliance with relevant law, such policies may also incorporate best practices that include extralegal norms such as business ethics. ${ }^{47}$ In this respect, compliance is concerned with managing risk. Rather than norm-enforcers externally imposing obligatory rules on a legal person, as in the case of criminal law or administrative sanctions, compliance consists of balancing risks through engaging with those multiple sources of norms. ${ }^{48}$

Through compliance, lawyers conduct these calculations before a norm violation occurs, in the form of a compliance program. In the event an employee of a company violates those norms, then the company may internally investigate the nature of the breach before (or sometimes after) regulators begin their investigation of the company. When clients are domiciled in one jurisdiction but conduct business in another, the question of which standard(s) to use is a threshold one. Lawyers have a certain amount of discretion in applying norms to their clients' business practices. As such, compliance entails practices of self-discipline, although such form of discipline respond to and, in

\footnotetext{
${ }^{46}$ See Parker \& Nielsen supra note 12, at 48; Benjamin van Rooij, Compliance: Understanding Legal and Social Approaches, in HEGUI: QUANQIU GONGSI FAZHAN XIN QUSHI (合规：全球公司发展新趋势) [Compliance: The New Development Trend of Global Companies] 102 (Jiang He \& Wang Zhile eds., 2012).

${ }^{47}$ Many MNCs have a compliance officer who coordinates compliance internally. Often, compliance officers themselves are not trained as lawyers. Yet, while there can be a division of labor between the compliance and law departments, the two are porous as both mitigate risk. Compliance officers seek legal counsel for issues that exceed their expertise or for when they want to gain assurances. See Michele DeStefano, Creating a Culture of Compliance: Why Departmentalization May Not Be the Answer, 10 HASTINGS BUS. L.J. 71, 130-31 (2013) (observing the close contacts between compliance officers and lawyers in a company, while also noting potential "turf wars").

${ }^{48}$ Gareth Adams, What Is Compliance?, 2 J. Fin. REg. \& CoMP. 278 (1994); Michael Clarke, What Is Compliance? The Moral Dimension, 3 J. FIN. REG. \& ComP. 123 (1995); Garry C. Gray \& Susan S. Silbey, Governing Inside the Organization: Interpreting Regulation and Compliance, 120 AMER. J. SOCIO. 96 (2014).
} 
turn, give shape to, broader regulatory and legal frames. ${ }^{49}$ Following a restructuring of corporate governance after the 2008 financial crisis, self-discipline is a growth industry. ${ }^{50}$

Compliance with anticorruption law across different regulatory environments sheds light on the operation of transnational law. Compliance (a practice) is situated between transplantation (both a state practice and a theory that purports to explain such practices) and choice of laws (a doctrine to resolve problems of practice). The theory of the transplant asserts, generally, that law moves from one jurisdiction to another, replacing local norms. ${ }^{51}$ Choice of law doctrine determines which law applies to a given question. ${ }^{52}$ Yet compliance shows lawyers working with multiple legal standards that operate in the same space. ${ }^{53}$ In the case of the FCPA and the PRC anticorruption movement, the very simultaneity of legal norms creates a specific market—one oriented toward preferences for what I call bicultural lawyers, those proficient in two legal systems, in this case, the United States and the PRC. A number of contingent factors-

\footnotetext{
${ }^{49}$ Michel Foucault famously distinguished discipline from laws of the sovereign. Whereas laws are imposed by the sovereign, discipline, which entails ethical as well as legal sources, is exercised from within by surveillance, normalization, and control, as well as punishment, correction, and education. See MICHEL FoucAult, Power/KNOWLEDGE: SEleCted INTERVIEWS AND OTHER WRITINGS, 1972-1977 121 (1980).

${ }^{50}$ Not only the FCPA, but also the 2002 Sarbanes-Oxley Act and the 2010 Dodd-Frank Wall Street Reform and Consumer Protection Act impose robust filing requirements on MNCs. On the growth of compliance, see, Anthony Effinger, The Rise of the Compliance Guru-and Banking Ire, BLOOMBERG (June 25, 2015), http://www.bloomberg.com/news/features/2015-06-25/compliance-is-now-calling-the-shots-and-bankersare-bristling; Gregory J. Millman \& Samuel Rubenfeld, Compliance Officer: Dream Career? As Fines Sting, a Hiring Spree for Risk and Compliance Staff, WALL ST. J. (Jan. 15, 2014), http://www.wsj.com/articles/SB10001424052702303330204579250722114538750; Michele DeStefano, The Chief Compliance Officer, 2 THE PRACTICE (July 2016), https://thepractice.law.harvard.edu/article/thechief-compliance-officer/ (noting companies are responding to the increasing complexity of regulation posteconomic crisis of 2008 through installing compliance officers). See also Steven Sampson, The Anticorruption Package, 15 EPHEMERA: THEORY \& POL. IN ORG. 115 (2015) (providing an assessment of the growth of the anticorruption industry).

${ }^{51}$ See Alan Watson, Legal Transplants: An Approach to Comparative LaW (1993).

${ }^{52}$ See, e.g., Michael Traynor, Conflict of Laws, Comparative Law, and the American Law Institute, 49 AMER. J. COMP. LAW 391 (2001). For PRC choice of law, see WeIZUO CHEN, ChINESE CIVIL PRocedure AND THE CONFLict of LAWs (2011); Zheng SoPhia TANG et al., Conflict of LAWS IN THE PEOPLE'S REPUBLIC OF CHINA (2016).

${ }^{53}$ See Paul Schiff Berman, Choice of Law and Jurisdiction on the Internet: Towards a Cosmopolitan Vision of Conflict of Laws: Redefining Governmental Interests in a Global Era, 153 U. PA. L. REV. 1819 (2005) (arguging for a cosmoplitan conception of choice of law to account for the overlapping affiliations people can have in plural communities).
} 
language, legal education, training, professional and social networks, lawyer licensing regimes, and U.S.-PRC relations - influence lawyers' abilities to apply the multiple legal norms of FCPA practice, and, in turn, these factors shape how and which norms they apply. The study of compliance is not just about who applies legal norms but how the transnational qualities of such norms may "select" their appliers. The broader prescriptive argument of this Article is that the study of transnational law benefits from a processual approach that brings attention to the mundane micropractices ${ }^{54}$ of those lawyers to understand the operation of law across borders. ${ }^{55}$ To do so, in the next section, I discuss my methodology.

\section{Methodology}

This Article underscores ethnography as a means of gaining purchase on the interaction of different legal systems. The basic assumption is that one way to advance the study of transnational law is to pay closer attention to the everyday practices of those cross-border lawyers engaged in compliance work. Ethnography is more familiar to social scientists of law than comparativists, and yet scholars have observed a rapprochement between "law and society" and comparative law, in part, through shared methods. ${ }^{56}$ Ethnography, however, is far from an unproblematic methodology and has

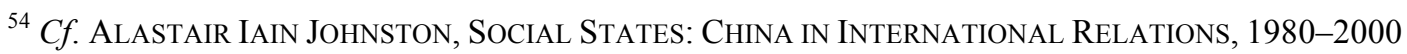
(2007) (studying the "microprocesses" of Chinese diplomats in their interactions with the global diplomatic community through mimicking, social influence, and persuasion).

${ }^{55}$ In recent years, anthropology has contributed to the study of modern financial actors in corporate settings. See, e.g., Gwendolyn Gordon, Culture in Corporate Law or: A Black Corporation, a Christian Corporation, and a Māori Corporation Walk into a Bar ..., 39 SeAtTle U. L. ReV. 353 (2016); Karen Ho, LiQuidated: An ETHNOGRAPHY OF WALl STREet (2009); ANNELISE RILES, Collateral KNOWLEDGE: Legal REASONING IN THE Global FinANCIAL MARKETS (2011); MARINA WELKER, ENACTING THE CORPORATION: AN AMERICAN MINING FIRM IN POST-AUTHORITARIAN INDONESIA (2014).

${ }^{56}$ Roger Cotterrell, Comparative Sociology of Law, in COMPARATIVE LAW AND SOCIETY 39, 41 (David Scott Clark ed., 2012); Lawrence M. Friedman, Some Thoughts on Comparative Legal Culture, in COMPARATIVE AND PRIVATE INTERNATIONAL LAW: ESSAYS IN HONOR OF JOHN HENRY MERRYMAN 49 (1990); Tom Ginsburg, Lawrence M. Friedman's Comparative Law, in LAW, SOCIETY AND HISTORY: ESSAYS ON THEMES IN THE LEGAL History AND LEgAL SOCIOLOGY OF LAWRENCE M. FRIEDMAN 52
} 
long been subject to criticism; as a consequence, it has emerged as a more refined and sensitive methodology. ${ }^{57}$ I turn to ethnography as a method to understand the processes that comprise the everyday of transnational legal work to understand how practitioners relate legal standards across different systems of law. Whereas comparativists often analyze legal problems from the height of 30,000 feet, ethnographic methods provide a counterweight through a "worm's eye" perspective, specifically, the view of practitioners who engage in cross-border law, and ethnographically-grounded analysis builds from such perspectives "upward."

The basis of my ethnographic approach is my own legal practice. From 2012 to 2013, I practiced corporate law in a U.S. law firm with offices in China. While conducting internal investigations in New York City, I participated in conversations with senior associates and partners, and attended training sessions. Prior to working in the New York City office, I worked in the Beijing office in 2007 to 2008, although as FCPA practice was, at that point, not yet developed in China ${ }^{58}$ I practiced other areas of law. However, my time in China allowed me to develop language skills (I had previously studied Chinese), knowledge of PRC law (I studied law at a Chinese law school), and contacts that were useful in gaining access to other U.S. law firms in China and PRC law firms. From that period onward, I was able to engage in conversations with lawyers, both Chinese and American, based in China. I broadened this network so that I was speaking

(Robert Gordon ed., 2010); Annelise Riles, Comparative Law and Socio-legal Studies, in THE OXFORD HANDBOOK OF COMPARATIVE LAW 775 (Mathias Reimann \& Reinhard Zimmermann eds., 2006).

${ }^{57}$ Didier FASSIn, ENForcing ORder: AN ETHNOGRAPHy OF URBAN POLICING (2013); John Flood, SocioLegal Ethnography, in THEORY AND METHOD IN SOCIO-LEGAL RESEACH 33 (2005); Kim Lane Scheppele, Constitutional Ethnography: An Introduction, 38 LAW \& SOC'Y REV. 389 (2004).

${ }^{58}$ For a brief history of the FCPA in the PRC, see infra text accompanying notes 117-131. 
with lawyers about FCPA matters in New York, Washington, D.C., Beijing, Shanghai, Hong Kong, and London.

In the course of these interactions, it became apparent that lawyers located in different offices of the same firm, or sometimes across firms, and even across sectors (particularly vis-à-vis governmental regulators) comprised, broadly speaking, transnational communities. Such communities were united by modes of living and thinking that were mostly dominated by their profession in "Big Law." Practicing law meant being accessible 24/7 through Blackberry e-mails, attending long hours of conference calls, and sometimes taking international flights between the U.S. and China offices to coordinate activities within the global law firm. ${ }^{59}$ In addition, compliance lawyers would attend conferences within their firm and international commercial conferences on developments in anticorruption compliance, during which they would come face-to-face with colleagues and competitors, respectively, acquiring awareness of "us" (and perhaps “them”).

In the summer of 2016, I conducted intensive fieldwork in Beijing and Shanghai, visiting the leading U.S. and PRC law firms with active FCPA practices. During that period, I spoke to forty-four lawyers. I conducted semistructured interviews that lasted from a half hour to three hours and were either in Chinese or English. ${ }^{60}$ In addition to lawyers, I interviewed regulators, officials, judges, compliance officers, risk consulting firms, and other vendors associated with what some commentators have called "FCPA

\footnotetext{
${ }^{59}$ On social scientific studies of global law firms, see James Faulconbridge \& Daniel Muzio, Reinserting the Professional into the Study of Global Professional Service Firms: The Case of Law, 7 GLOBAL NETWORKS 249 (2007); John Flood, Institutional Bridging: How Large Law Firms Engage in Globalization, 54 B.C. L. REV. 1 (2013); Glenn Morgan \& Sigrid Quack, Institutional Legacies and Firm Dynamics: The Internationalization of British and German Law Firms, 26 ORG. STUD. 1765 (2005).

${ }^{60}$ As my interviewees requested anonymity, I provide place and date of interview only.
} 
Inc." I also assessed major FCPA cases, and collected primary source material from law firms, including their internal memos and publications (e.g., "client alerts" and memos).

In the following section, I provide an overview of the relevant regulatory systems.

\section{Two and a Half Regulatory Regimes}

The lawyers who practice FCPA assess, depending on their position in the community, up to two and a half anticorruption regimes: the first is the FCPA itself and the second is the PRC anticorruption regime, which includes PRC law; and "the half" includes the internal rules of the CCP. ${ }^{61}$ The FCPA and the PRC anticorruption campaign derive from starkly different origins, yet they converge in regulating the behavior of members of the business community in China. In this section, I explain their specific standards and how, through their interaction, they have expanded through the everevolving nature of their enforcement. The result of these interactions is not displacement but rather simultaneity, as norms coexist in lawyers' legal analyses that are adopted by MNCs in China.

\section{The FCPA}

The FCPA, a product of the mid-1970s Watergate scandal, has undergone major transformations since its origins, more in terms of enforcement than amendments. Originally passed by Congress to increase transparency among U.S. businesses operating

\footnotetext{
${ }^{61}$ Scholars are increasingly paying attention to the role of Party rules in shaping the nature of legal reform in China. See Larry Catá Backer, Party, People, Government and State: On Constitutional Values and the Legitimacy of the Chinese State-Party Rule of Law System, 30 B.U. InT’L L.J. 101 (2010); Jianfu Chen, Out of the Shadows and Back to the Future: CPC and Law in China, 24 ASIA PAC. L. REV. 176 (2016); Li supra note 4; FlORA SAPIO, SOVEREIGN POWER AND THE LAW IN CHINA (2010); Suli Zhu (朱苏力), Zhongguo Sifa Zhong de Zhengdang (中国司法中的政党) [The Political Party in Chinese Justice System], 1 FALÜ HE SHEHUI KEXUE (法律和社会科学) [LAW \& SOC. SCI.] 256 (2005).
} 
overseas, the FCPA represents one attempt by the U.S. government to align best practices in the private sector with public values. ${ }^{62}$ The FCPA consists of two main provisions: the antibribery provisions and the accounting provisions. The former prohibit U.S. persons and business (“domestic concerns"), U.S. and foreign public companies listed on stock exchanges in the United States ("issuers"), and certain foreign persons and businesses operating in the territory of the United States ("territorial jurisdiction") from providing unlawful benefits to foreign officials for business purposes. ${ }^{63}$ The latter consist of the "books and records" provision that requires issuers to make and keep books, records, and accounts that, in reasonable detail, reflect an issuer's transactions ${ }^{64}$ and the "internal controls" provision that requires issuers to maintain a system of internal accounting controls sufficient to assure managerial control over its assets. ${ }^{65}$ Under the antibribery provisions, the DOJ can impose criminal liability on those who violate its requirements, whereas the SEC is empowered by the accounting provisions to impose civil liability. In the course of their compliance work, lawyers evaluate both sets of provisions, but more attention is often paid to the antibribery provisions as they are broader in scope ${ }^{66}$ and require more analysis. ${ }^{67}$

There are two distinguishing features of the antibribery provisions that warrant attention: their extraterritorial jurisdiction and voluntary disclosure. In regard to the

\footnotetext{
${ }^{62}$ See U.S. Dep'T OF Justice \& SeC. AND EXCh. COMm'N, supra note 7, at 104 (citing U.S. AgENCY FOR INT'L DEV., USAID ANTICORRUPTION STRATEGY 5-6 (2005) stating, "[w]idespread corruption endangers the stability and security of societies, undermines democracy, and jeopardizes the social, political, and economic development of societies ...").

${ }^{63} 15$ U.S.C. $\S 78 \mathrm{dd}-1$ (2012).

${ }^{64} I d . \S 78 \mathrm{~m}(\mathrm{~b})(2)(\mathrm{A})$.

${ }^{65} \mathrm{Id} . \S 78 \mathrm{~m}(\mathrm{~b})(2)(\mathrm{B})$.

${ }^{66}$ The accounting provisions apply only to "issuers." See infra note 70.

${ }^{67}$ Generally, violations of the antibribery provisions are harder to prove. To do so, one must show evidence of bribery that is more difficult than a violation of the accounting provisions that only requires one to show a "control failure," meaning that money was lost. Furthermore, the standard for the antibribery provisions is "beyond a reasonable doubt," which is a higher bar than that of the accounting provisions' civil standard of preponderance of evidence.
} 
question of jurisdiction, the FCPA has been called the "first law in the world governing domestic business conduct with foreign government officials in foreign markets." 68 The FCPA has different jurisdictions depending on the nature of the business entity or person subject to its requirements. ${ }^{69}$ For "issuers" "70 and "domestic concerns," FCPA's long-arm jurisdiction stems from a 1998 amendment to the statute that extended its jurisdiction beyond territorial jurisdiction to include the "nationality principle." means that whereas territorial jurisdiction depends on using the U.S. mails or any means or instrumentality of interstate commerce in furtherance of a corrupt payment, nationality jurisdiction removed the requirement of using interstate commerce for acts that further corrupt payment to a foreign official, meaning that the FCPA can be violated even if an improper payment is made outside of the United States. ${ }^{73}$ The result of this extraterritorial jurisdiction is that U.S. companies can be prosecuted for the conduct of their subsidiaries abroad.

The second outstanding feature of the FCPA is voluntary disclosure, which means that the DOJ and SEC have created an enforcement structure that privileges self-reporting

\footnotetext{
${ }^{68}$ Thomas O. Gorman, The Origins of the FCPA: Lessons for Effective Compliance and Enforcement, 43 SeC. REg. L.J., 43, 59 (2015). See also Mike Koehler, The Story of the Foreign Corrupt Practices Act, 73 Оніо ST. L.J., 930, 934 (2012) [hereinafter Koehler, The Story of the FCPA] (explaining that U.S. MNCs had made questionable payments to foreign government officials in relation to a business purpose).

${ }^{69} 15$ U.S.C. § 78dd-3. See Mike Koehler, Into the FCPA's Jurisdiction Thicket (Apr. 28, 2015), http://fcpaprofessor.com/into-the-fcpas-jurisdictional-thicket/ [hereinafter Koehler, Jurisdiction Thicket]. ${ }^{70} 15$ U.S.C. § 78dd-1. See also U.S. DeP’T OF JUSTICE \& SEC. AND EXCH. COMM’N, supra note 7, at 11 (explaining a company is an "issuer" if it has a class of securities registered under section 12 of the Exchange Act or is required to file periodic reports with the SEC under section 15(d) of the Exchange Act).

${ }^{71} 15$ U.S.C. § 78dd-2. See also U.S. DeP'T OF JustiCE \& SEC. AND EXCH. CoMm'N, supra note 7, at 11 (defining "domestic concern" as any individual who is a national of the United States or any corporation organized under the laws of the United States).

${ }^{72}$ See U.S. DeP'T OF Justice \& SEC. AND EXCH. COMm'N, supra note 7 at 12 n.62 (citing the 1997 Organization for Economic Cooperation and Development's Convention on Combating Bribery of Foreign Public Officials in International Business Transactions (hereinafter, the OECD Convention) as cause for the amendment).

${ }^{73}$ See Koehler Jurisdiction Thicket, supra note 69; U.S. DeP'T OF JUSTICE \& SEC. AND EXCH. COMM'N, supra note 7, at 12. See also United States v. Giffen, No. 03-cr-663 (S.D.N.Y. 2003) (charging defendant with violating the FCPA for allegedly providing millions of dollars in bribes to Kazakh officials to retain business).
} 
by corporations of potential violations of the FCPA in exchange for rewards such as mitigation. ${ }^{74}$ It is important to note that the FCPA itself does not mandate voluntary disclosure; rather, disclosure is a result of the way that the law is enforced. Since the antibribery provisions criminalize foreign corrupt bribery, the DOJ and the SEC may mitigate or excuse criminal liability through deferred prosecution agreements (DPAs) and nonprosecution agreements (NPAs). Upon discovery of wrongdoing, the MNC signs these agreements with the DOJ or SEC, and foregoes prosecution in favor of paying fines as well as other remedial measures, for example, installing a third-party monitor.

Consequently, MNCs opt for settlement with the U.S. government as opposed to litigation that can cause reputational harm. ${ }^{75}$ Self-reporting was meant to encourage corporate governance and good stewardship of shareholder funds. ${ }^{76}$ Yet it also addresses some of the costly challenges the U.S. government faces in enforcing the antibribery provisions, including acquiring testimony and collecting evidence overseas and coordinating with foreign governments that may be reluctant to work with the U.S. government. $^{77}$

\footnotetext{
${ }^{74}$ William S. Laufer, Corporate Prosecution, Cooperation, and the Trading of Favors, 87 IowA L. REV. 643, 646 (2002). Several critics have pointed out that the specific rewards for self-disclosure are poorly defined. See Elkan Abramowitz \& Jonathan Sack, Dilemma of Self-Reporting: The FCPA Experience, 251 N.Y. L.J. 1 (2014); Peter R. Reilly, Incentivizing Corporate America to Eradicate Transnational Bribery Worldwide: Federal Transparency and Voluntary Disclosure Under the Foreign Corrupt Practices Act, 67 FL. L. REV. 1683 (2015).

${ }^{75}$ But see Searle Civil Justice Institute, The Foreign Corrupt Practices Act: ECONOMiC Impact ON TARGETED FIRMS (2014) (showing that MNCs charged with bribery on average experienced only a $1.5 \%$ reduction in market capitalization, whereas those charged with both bribery and financial fraud experienced an initial loss of $16.3 \%$ ).

${ }^{76}$ See Gorman, supra note 68, at 51. See also Criminal Division of DOJ, Criminal Division Launches New FCPA Pilot Program, DOJ (Apr. 5, 2016), https://www.justice.gov/opa/blog/criminal-division-launchesnew-fcpa-pilot-program (announcing that the DOJ is establishing a pilot "credit" program that would mitigate punishments for FCPA violations); Fred Yeager et al., US Legislation Designed to Improve Corporate Governance: An Exploration, 33 COMPANY LAW, 25 (2012).

${ }^{77}$ The legislative history of the FCPA reflects such foresight. See Koehler, The Story of the FCPA, supra note 68, at 997 (citing a May 1977 Senate Report stating, in part, "The criminalization of foreign corrupt bribery will to a significant extent act as a self-enforcing, preventive mechanism")
} 
As a result of voluntary disclosure, MNCs have developed compliance programs to internally monitor their employees' expenses and use of company funds. Selfreporting, combined with the extraterritorial jurisdiction of the FCPA, has caused MNCs to spend massive amounts of money, a source of abiding controversy. ${ }^{78}$ While the FCPA had been largely dormant for the first two decades since its enactment, ${ }^{79}$ beginning in the 2000 s, prosecutions increased ${ }^{80}$ and witnessed a boom after the 2008 global financial crisis for reasons I explain below. From 2007 to 2015, there were 115 corporate (i.e., not including individuals) enforcement actions, by both the DOJ and SEC, from which the U.S. government generated a total of $\$ 6.37$ billion. $^{81}$

To return to the question at the start of the Article, the U.S. government has defined "anything of value" expansively for corrupt business transactions in China. The term has referred to a broad range of improper benefits including cash (e.g., consulting fees or commission to intermediaries), ${ }^{82}$ gifts, ${ }^{83}$ travel and entertainment, ${ }^{84}$ and charitable

\footnotetext{
${ }^{78}$ See Poneman Institute, The True Cost of Compliance: A Benchmark Study of Multinational ORGANIZATIONS 1-2 (2011) (finding that among $46 \mathrm{MNCs}$, the average total cost of compliance was $\$ 3.5$ million, whereas the cost of noncompliance was 2.65 times greater or $\$ 9.4$ million). See also Gorman, supra note 68, at 43 (writing that "self-reporting might be viewed as effectively writing a series of blank checks to law firms. .."); Mike Koehler, Donald Trump: The FCPA Is a "Horrible Law and It Should Be Changed" FCPA PROFESSOR (Aug. 6, 2015), http://fcpaprofessor.com/donald-trump-the-fcpa-is-a-horriblelaw-and-it-should-be-changed/ (quoting Donald Trump who called FCPA enforcement "absolutely crazy").

${ }^{79}$ Cortney C. Thomas, The Foreign Corrupt Practices Act: A Decade of Rapid Expansion Explained, Defended, and Justified, 29 REV. Litig. 439, 449 (observing that from 1977 to 1997, only seventeen companies and thirty-three individuals were charged under the FCPA).

${ }^{80}$ Tor Krever, Curbing Corruption? The Efficacy of the Foreign Corrupt Practices Act, 33 N.C. J. INT’L L. \& COMM'L REG. 84, 95 (2007).

${ }^{81}$ Corporate FCPA Enforcement In 2015 Compared To Prior Years, FCPA PROFESSOR (Jan. 7, 2015), http://fcpaprofessor.com/corporate-fcpa-enforcement-in-2015-compared-to-prior-years/.

${ }^{82}$ See SEC, SEC Files Settled Foreign Corrupt Practices Act Charges Against Siemens AG for Engaging In Worldwide Bribery With Total Disgorgement and Criminal Fines Of Over \$1.6 Billion SEC (Dec. 15, 2008), https://www.sec.gov/litigation/litreleases/2008/lr20829.htm (alleging that Siemens engaged in a "widespread and systemic practice of paying bribes to foreign officials" including those in China) and DOJ, RAE Systems Agrees to Pay \$1.7 Million Criminal Penalty To Resolve Violations Of The Foreign Corrupt Practices Act DOJ (Dec. 10, 2010), https://www.justice.gov/opa/pr/rae-systems-agrees-pay-17-millioncriminal-penalty-resolve-violations-foreign-corrupt (finding that RAE Systems engaged in "improper commissions, kickbacks and "under table greasing to get deals").
} 
contributions $^{85}$ (see Appendices for complete listing). By expanding definitions of corruption beyond material benefits like cash to immaterial ones extending to family members, such as in the JP Morgan case whereby the company gave internship opportunities to the children of officials,${ }^{86}$ the DOJ and SEC have tracked the Chinese gift economy - with its reproduction of ties often predicated on familial or kin relationsthrough FCPA enforcements. Just as the U.S. Government has taken an expansive view of corruption as "anything of value," so, too, must FCPA lawyers seeking to protect their clients from investigations. Yet the FCPA is not the only anticorruption regime operating in China; lawyers must also assess the PRC anticorruption campaign that constructs anticorruption on a different set of terms.

\section{The PRC Anticorruption Campaign}

The second (and a half) anticorruption regime is that of the PRC, which includes PRC law and CCP rules. The anticorruption campaign began in 2012 as Xi Jinping assumed power; it has generally been perceived as a political movement meant to

\footnotetext{
${ }^{83}$ See DOJ, Avon China Pleads Guilty to Violating the FCPA by Concealing More Than $\$ 8$ Million In Gifts To Chinese Officials DOJ (Dec. 17, 2014), https://www.justice.gov/opa/pr/avon-china-pleads-guiltyviolating-fcpa-concealing-more-8-million-gifts-chinese-officials and SEC, SEC Charges California Telecommunications Company with FCPA Violations SEC (June 29, 2010), https://www.sec.gov/litigation/litreleases/2010/lr21581.htm (alleging that Veraz gave $\$ 40,000$ to officials as part of a "gift scheme").

${ }^{84}$ See DOJ, PTC Inc. Subsidiaries Agree To Pay More Than $\$ 14$ Million To Resolve Foreign Bribery Charges DOJ (Feb. 16, 2016), https://www.justice.gov/opa/pr/ptc-inc-subsidiaries-agree-pay-more-14million-resolve-foreign-bribery-charges (finding that Parametric paid over $\$ 1$ million for recreational travel for employees of Chinese state-owned enterprises to travel to New York, Los Angeles, Law Vegas, and Hawaii.)

${ }^{85}$ See SEC, SEC Charges Nu Skin Enterprises, Inc. With FCPA Violations (Sept. 20, 2016), https://www.sec.gov/litigation/admin/2016/34-78884-s.pdf SEC (finding that Nu Skin made a 1 million RMB donation to a charity identified by a CCP official to avoid an investigation by the Administration of Industry and Commerce.)

${ }^{86}$ See DOJ, JPMorgan's Investment Bank In Hong Kong Agrees To Pay $\$ 72$ Million Penalty For Corrupt Hiring Scheme In China DOJ (Nov. 17, 2016), https://www.justice.gov/opa/pr/jpmorgan-s-investmentbank-hong-kong-agrees-pay-72-million-penalty-corrupt-hiring-scheme. See also SEC, Qualcomm Hired Relatives of Chinese Officials To Obtain Business SEC (Mar. 1, 2016), https://www.sec.gov/news/pressrelease/2016-36.html.
} 
consolidate Xi's control over the CCP and increase the legitimacy of the Party in the eyes of the Chinese nation by imposing harsh penalties on Party members who are deemed to be corrupt. Whereas the fall of the so-called tigers (high-ranking PRC officials) has received media scrutiny, the $\mathrm{CCP}$ has also conducted probes of a number of industries: pharmaceutical, automobile, telecom, securities, and the airline industry. While the anticorruption drive has been regarded primarily as a result of internal drivers, its legal dimensions have also been influenced by international law and foreign law. ${ }^{87}$ Likewise, while the campaign's impacts are principally domestic in nature, it has also impacted the operations of MNCs across borders.

There are two sources of norms operative in the domestic campaign against official corruption, including criminal law and internal CCP rules (dangnei guize), to which government officials are both beholden. Accordingly, the campaign is carried out through both formal legal channels, that is, investigations by procurators and cases heard by criminal courts, and also CCP extralegal methods, organized by the Central Commission for Discipline Inspection of the CCP (CCDI or Zhong Jiwei) ${ }^{88}$ On the

\footnotetext{
${ }^{87}$ In 2011, the PRC Criminal Law was amended to include article 164, which has been called "China's FCPA," since it penalizes employees of PRC companies who bribe officials abroad. While the amendment is widely perceived as a result of conformity with the 2003 U.N. Convention Against Corruption (hereinafter UNCAC), U.S. Department of Commerce General Counsel Cameron Kerry advocated for China to adopt a U.S.-like antibribery law in 2011, suggesting that there is some evidence of transplantation between the anticorruption regimes. See U.S. Dep't of Commerce, General Counsel Kerry Travels to China for the US-China Joint Liaison Group Anti-Corruption Working Group, (Aug. 1, 2011), http://20102014.commerce.gov/os/ogc/developments/general-counsel-kerry-travels-china-us-china-joint-liaisongroup-anti-corruption.html. International law, in the form of the UNCAC, the OECD Convention, and European Union law (China being influenced by only the first of these), has shaped the extraterritorial jurisdiction of anticorruption legislation in a number of states. As of 2011, 178 countries have adopted anticorruption legislation. See United Nations Office on Drugs and Crime, UNCAC Legal Library Launched: New Database of Anti-Corruption Legislation from 178 States, Central Asia (Sept. 1, 2011), https://www.unodc.org/centralasia/en/press/uncac-legal-library-launched_-new-database-of-anticorruption-legislation-from-178-states.html. On the influence of UNCAC on China's anticorruption law, see Yao supra note 9; Margaret K. Lewis, Corruption: Spurring China to Engage in International Law, 1 ChInA RTS, F. 90 (2009).

${ }^{88}$ The CCDI is an organ of the CCP that has grown more powerful since the 1980s. See Li supra note 4, at 451-55. It is mirrored on the government side by the Ministry of Supervision (Jiancha ju), and, in fact,
} 
formal law side, the main legislation is the PRC Criminal $\mathrm{Law}^{89}$ that prohibits official bribery and the Anti-Unfair Competition Law (AUCL) ${ }^{90}$ that penalizes commercial bribery through imposing civil and administrative penalties.

As a result of the anticorruption campaign, the PRC Criminal Law has undergone revisions that clarify its antibribery provisions. As explained to me by a judge in Beijing, the PRC Criminal Law differentiates between the bribe giver (xinghui) and the bribe recipient (shouhui), with a greater focus on the latter. ${ }^{91}$ Up until 1997, the PRC Criminal Law criminalized the receiving of bribes by government officials and defined them using monetary thresholds. ${ }^{92}$ The ninth amendment to the PRC Criminal Law in November 2015 replaced these monetary thresholds with gradations of amounts: "relatively large" (jiaoda), "huge" (juda), and "especially large" (tebie juda). These allow for greater judicial discretion but also exacerbated the lack of uniformity in enforcements. ${ }^{93}$ However, the April 2016 judicial interpretation of the ninth amendment reinserted statutory minimums, adjusted for inflation. ${ }^{94}$

most members wear both hats, so when they meet with members of foreign states, they do so in their capacity as the latter.

${ }^{89}$ Zhonghua Renmin Gongheguo Xingfa (中华人民共和国刑法) [PRC Criminal Law], adopted at the Second Session of the Fifth National People's Congress, July 1, 1979, and amended at the Fifth Session of the Eighth National People's Congress on Mar. 14, 1997.

${ }^{90}$ Zhonghua Renmin Gongheguo Fan Bu Zhengdang Jingzheng Fa (中华人民共和国反不正当竞争法) [Anti-Unfair Competition Law of the PRC] (Draft Amendment Submitted for Approval), Legislative Affairs Office of the State Council, Feb. 25, 2016.

${ }^{91}$ The judge and PRC lawyers I spoke to attributed this to priorities in traditional Chinese law that placed more emphasis on the recipient as the one who directly harms the interests of the government. Interviews, Beijing, Aug 13, 2016.

${ }^{92}$ See supra note 89 , art. 383 (setting the statutory minimum for receiving bribes at 5,000 renminbi or RMB, about \$727).

${ }^{93}$ Zhonghua Renmin Gongheguo Xingfa Xiu Zheng'an (Jiu) (中华人民共和国刑法修正案（九）) [Amendment Nine to the PRC Criminal Law], issued by the Standing Committee of the NPC, Aug. 29, 2015 (amending art. 383). See also Ananda Martin et al., Recent Developments Strengthen Chinese AntiBribery Law, Paul Hastings (May 19, 2016), http://www.paulhastings.com/publicationsitems/details/?id=5060e969-2334-6428-811c-ff00004cbded.

${ }^{94}$ Zuigao Renmin Fayuan, Zuigao Renmin Jianchayuan Guanyu Banli Tanwu Huilu Xingshi Anjian Shiyong Falü Ruogan Wenti de Jieshi (最高人民法院, 最高人民检察院关于办理贪污贿赂刑事案件使 
Along with the revisions to the PRC Criminal Law, the AUCL has also undergone revisions in the course of the anticorruption campaign. The AUCL prohibits commercial bribery defined as that committed between businesses in the course of their dealings. On February 25, 2016, the State Council published the AUCL Draft Amendment to update the AUCL. The revisions, including broadening the definition of commercial bribery and prohibiting the use of third parties to facilitate bribing, illustrate that the anticorruption campaign has evolved to prohibit unfair commercial benefits. ${ }^{95}$ Judges and lawyers perceived the revisions to both the PRC Criminal Law and the AUCL as the government's attempt to increase regulation of corrupt behavior. However, some have argued that the anticorruption drive has had negative impacts on the Chinese economy, and has contributed to the slowdown as China transitions from an economy oriented toward exports to one based on consumers. ${ }^{96}$

The system that parallels that of the formal criminal justice system is led by the CCDI and is aimed at reforming the behavior of Party members. As opposed to legal sanction, the CCDI deals with what one judge called "leading an honest and clean life" (jieshenzihao). ${ }^{97}$ It does so by promulgating rules that are more ethical and moralistic than legal in nature. In December 2012, the Central Committee of the CCP issued the so-

用法律若干问题的解释) [Supreme People's Court and Supreme People's Procuratorate's Judicial Interpretation Regarding the Application of the Law in Anticorruption and Anti-Bribery Criminal Cases], jointly issued by the Supreme People's Court and the Supreme People's Procuratorate, Apr. 18, 2016, art. 1 (setting the statutory minimum for receiving bribes to 30,000 RMB, about \$4,360). See also Martin et al. supra note 93 , at $1-2$.

${ }_{95}$ See supra note 90 , arts. 2 and 7.

${ }^{96}$ Chan Huan Jun \& Lin Xueling, Corruption Clean-up Is Top Reason for China's Slowdown: Former Central Banker, Channel NewsAsia (July 27, 2016), http://www.channelnewsasia.com/news/asiapacific/corruption-clean-up-is/2990472.html\# (citing Li Daokui, former People's Bank of China policy maker saying that the anticorruption drive was the major reason for the slowdown). There is evidence that the anticorruption campaign has negatively impacted certain sectors of the economy such as the production of luxury goods. See DeloitTE, Global Powers of LUXURY GOODS 2015: ENGAGING THE FUTURE LUXURY CONSUMER 3-4 (2016) (attributing the deceleration in spending in part to the anticorruption campaign).

${ }^{97}$ Interview, Beijing, Aug. 13, 2016. 
called Eight Rules (ba xiang guiding) that call for the improvements of cadres' work. ${ }^{98}$ In subsequent years, Party organs have issued a number of similar behavior codes, for instance, the "Chinese Communist Party Standards on Incorruptible Self-Discipline." 99 The CCDI, a vestige of Leninist organization, ${ }^{100}$ investigates and punishes violations of these codes, and publicizes punishments. ${ }^{101}$ The procedure through which the CCDI leads investigations is known as shuanggui, which does not follow criminal procedure law. Lasting several months or more, the procedure consists of collecting evidence, gathering testimony, and detaining the subject. ${ }^{102}$ Because of its lack of due process, shuanggui has been subject to steady criticism. ${ }^{103}$ Some Chinese lawyers mentioned procedural rules as evidence of increasing transparency, although they acknowledged the process was still entirely secretive. ${ }^{104}$ According to official media, in 2014, the CCDI handled 73,332

\footnotetext{
${ }^{98}$ Zhong-Gong Zhongyang Zhengzhiju Guanyu Gaijin Gongzuo Zuofeng Miqie Lianxi Qunzhong de Guiding (中共中央政治局关于改进工作作风密切联系群众的规定) [Central Committee of the CCP's Political Bureau's Rules for Improving the Work Style of those [Cadres] in Close Contact with the Masses], issued by the Central Committee of the CCP's Political Bureau, Dec. 4, 2012 [hereinafter, the Eight Rules] (calling for improving investigative research, meetings, documentation and report writing, visting foreign states, security work, publication work, and incorruptibility).

${ }^{99}$ Zhongguo Gongchandang Lianjie Zilü Zhunze (中国共产党廉洁自律准则) [Chinese Communist Party Standards on Incorruptible Self-Discipline], Central Committee of the Chinese Communist Party, Oct. 12, 2015 (advocating, as in article 7, "incorruptible cultivation of one's character, consciously promote thought and morality in one's environment"). See also Zhongguo Gongchandang dangyuan lingdao ganbu lianjie congzheng ruogan zhunze (中国共产党党员领导干部廉洁从政若干准则) [Several Standards of Chinese Communist Party Members and Leading Cadres' Incorruptible Engagement in Politics], issued by the Central Committee of the CCP, Jan. 1, 2016.

${ }^{100}$ See Li supra note 4; Frank Pieke, The Good Communist: Elite Training AND STATE Building IN TODAY's CHINA 7, 55-56, 60, 77, 86 (2009).

${ }^{101}$ Zhongyang Jiwei Jianchabu Wangzhan (中央纪委监察部网站) [CCDI Supervision Department Website], Zhongjiwei Fabu Meizhou Tongbao: 96 Qi Weifan Ba Xiang Guiding Jingshen Wenti Bei Chachu (中纪委发布每周通报：96 起违反八项规定精神问题被查处) [CCDI issues the weekly public notice: Issues attendant to 96 cases of violating the spirit of the Eight Rules have been investigated and prosecuted] (2016), http://fanfu.people.com.cn/n1/2016/0128/c64371-28091992.html.

${ }^{102}$ Interviews with judges and lawyers in Beijing, Aug. 12 and 13, 2016.

${ }^{103}$ See Li supra note 4, at 468; See SAPIO, supra note 61.

${ }^{104}$ Zhongguo Gongchandang Jilü Jiancha Jiguan Anjian Jiancha Gongzuo Tiaoli (中国共产党记律检查机 关案件检查工作条例) [Chinese Communist Party Discipline Inspection Organs' Case Detail Work], issued by the Central Committee of the CCP CCDI, Mar. 25, 1994; Zhongguo Gongchandang Jilü Jiancha Jiguan Anjian Jiancha Gongzuo Tiaoli Shishi Xize (中国共产党纪律检查机关案件检查工作条例实施细 则) [Regulations Implementing Detailed Rules and Regulations for the CCP Discipline Inspection Organs'
} 
“Eight Rules" cases and investigated 96,788 cadres of whom 29,026 were disciplined; in 2015, the CCDI filed a total of 330,000 cases for inspection and prosecution (including 37,000 “Eight Rules” cases), and disciplined 336,000 individuals. ${ }^{105}$ These numbers are greater than the number of anticorruption cases tried by PRC courts in those same years: 31,000 (in 2014) and 34,000 (in 2015), suggesting that the CCDI has greater reach than the courts. ${ }^{106}$

The two normative systems - the PRC legal system and the CCP internal rulesare not wholly separate. Procedurally, a procurator of the Department of Anticorruption and Bribery under the Supreme People's Procuratorate is, according to law, supposed to lead an investigation into official corruption. However, in practice, there is a "prerequisite process" (qianzhi) by which the CCDI initiates the investigation. ${ }^{107}$ The CCDI subjects the official to shuanggui. Upon completion of the CCDI's investigation, the case then goes to the procurator who will apply state law and cannot rely on evidence collected by the CCDI, although lawyers admit that often the procurator takes part in the initial CCDI investigation.

Case Detail Work], issued by the Central Committee of the CCP CCDI, Mar. 25, 1994; and Guanyu Jijian Jiancha Jiguan Yange Yiji Yifa Ban'an de Yijian (关于纪检监察机关严格依纪依法办案的意见)

[Opinion Regarding Disciplinary Examination Supervision Organs' Strict Adherence to Discipline and Law in Handling Cases] issued by the Central Committee of the CCP CCDI, May 2005.

${ }^{105}$ Jie Jiang (姜洁), 2014 nian Zhongyang Jiwei Chaban Anjian Shuju Da Gaige Kaifang Yilai Zui Gaozhi (2014 年中央纪委查办案件数据达改革开放以来最高值) [The Number of Cases Investigated and Handled by the CCDI in 2014 Have Been the Highest in the Reform and Opening Period], RENMIN RiBAO ( 人民日报) [PEOPLE'S DAILY], Jan. 9, 2015, http://law.chinaso.com/detail/20150109/1000200032772961420771674692476951_1.html; Yang Zhou (周 阳), Zhong Jiwei: 2015 Nian Quanguo Gong Li'an 33 Wan Jian Chufen 33.6 Wan Ren (中纪委：2015 年 全国共立案 33 万件处分 33.6 万人) [CCDI: In 2015, 330,000 Cases Were Filed and Prosecuted for the Whole Country and 336,000 Individuals Were Disciplined] (Jan. 15, 2016), http://china.huanqiu.com/hot/2016-01/8388256.html.

${ }^{106}$ Chang Liu, China Put 49,000 People on Trial for Graft in 2015, FCPA BLOG (June 7, 2016), http://www.fcpablog.com/blog/2016/6/7/chang-liu-china-put-49000-people-on-trial-for-graft-in-2015.html. It is unclear from official statistics whether the criminal cases had previously gone through the CCDI system of shuanggui.

${ }^{107}$ See Fenfei Li \& Jinting Deng, The Power and the Misuse of Power by China's Local Procuratorates in Anticorruption, 45 InT'L J.L., CRIME AND JustiCE, 1, 3 (2016). 
Substantively, there is also overlap. A 1993 rule (hereinafter, the "1993 rule") issued by the State Council sets the limit of a gift to an official at 200 yuan, anything above which must be "passed up" to the higher-level official. ${ }^{108}$ A former procurator called this a "legal regulation" (fagui), one enforced jointly by the CCDI and the procurator. Although this minimum imposes reporting requirements on officials and the statutory minimum for bribery is much higher $(30,000 \mathrm{RMB}),{ }^{109}$ PRC lawyers told me that violation of the 1993 rule was enough to put an official on the radar of the CCDI. Hence, to return to the question that began this Article - the meaning of "anything of value" - in the context of the Chinese anticorruption campaign, there is a bright-line maximum.

To summarize the differences between the two regimes of the FCPA and the PRC anticorruption campaign, there are several points worth emphasizing. ${ }^{110}$ First, while the FCPA operates primarily through voluntary disclosure in addition to imposing civil penalties as well as criminalization, the PRC anticorruption regime emphasizes criminal, civil, and administrative liability over voluntary disclosure. ${ }^{11}$ Because of the emphasis on self-reporting under the FCPA, compliance has become the operative method of

\footnotetext{
${ }^{108}$ Guowuyuan Guanyu Zai Duiwai Gongwu Huodong Zhong Zengsong he Jieshou Lipin de Guiding (国务 院关于在对外公务活动中赠送和接受礼品的规定) [State Council Provision Regarding Offering or Receiving Gifts in the Course of a Public Affairs Activity], issued by the State Council, Dec. 5, 1993, art. 7. Practices Act, 73 OHIO ST. L.J. 1015 (2012); Yunxia Yin et al., Qiye Neng Dongxing yu Fanfabai “Fushexing Zhifa Xiaoying”-Meiguo FCPA Jezuo Jiizhi de Qishi (企业能动性与法腐败“辐射型执法效 应”一美国 FCPA 合作机制的启示) [The Dynamic Role of Enterprises and the Anticorruption's Effect of the Radiating-Type Legal Enforcement Effect: Inspiration for a Mechanism that Coordinates the U.S. FCPA], 2 JiAODA FAXUE (交大法学) [JiAOTONG U. LEGAL STUD.] 98 (2016).

${ }^{111}$ Under the FCPA, the SEC may also impose civil and administrative liability for violations of the accounting provisions. See 17 C.F.R. § 240.13b2-1 (2001).
} 
regulation. Whereas compliance has a strong role in Chinese law and regulation, ${ }^{12}$ the PRC anticorruption regime, as it impacts most spheres of official and commercial activities, operates more through command and control, ${ }^{113}$ with the exception of its overlap with the FCPA, as I explain below, which is compliance based.

Second, PRC antibribery law focuses on receiving bribes, but it also criminalizes giving bribes; ${ }^{114}$ the FCPA only focuses on the latter. Hence, FCPA punishes the supply side and the PRC law focuses on the demand side. In practice, these emphases are complementary as the bribe giver may be a U.S. MNC and the bribe recipient a PRC official. Third, the FCPA has no thresholds for bribery, whereas PRC law, including the 1993 rule, does. Given the complementary nature of the rules, lawyers may choose to "enforce" the PRC monetary amounts. Fourth, and in addition to the legal differences, the PRC campaign further includes the CCP internal rules and opaque procedures that diverge significantly from the regulatory procedures of the FCPA. The powers of the CCDI appear to be increasing following the anticorruption drive, a trend that may erode China's commitments to law. ${ }^{115}$

\footnotetext{
${ }^{112}$ Benjamin van Rooij, The People's Regulation, Citizens and Implementation of Law in China, 25 COLUM. J. ASIAN L. 116 (2012); BENJAMIN VAN ROOIJ, REgUlating LAND AND POLLUTION IN CHINA, LAWMAKING, COMPLIANCE, AND ENFORCEMENT; THEORY AND CASES (2006).

${ }^{113}$ See infra note 171 (explaining that without a procedure for voluntary disclosure and settlement, the PRC anticorruption regime has not seen an emphasis on compliance).

${ }^{114}$ Zuigao Renmin Fayuan, Zuigao Renmin Jianchayuan Guanyu Banli Tanwu Huilu Xingshi Anjian Shiyong Falü Ruogan Wenti de Jieshi (最高人民法院, 最高人民检察院关于办理贪污贿赂刑事案件适 用法律若干问题的解释) [Supreme People's Court and Supreme People's Procuratorate's Interpretation of Certain Problems Regarding Using Law to Handle Criminal Cases of Bribing Officials], issued by the Supreme People's Court and Supreme People's Procuratorate, Mar. 28, 2016.

${ }^{115}$ There are discussions to establish a State Supervisory Commission (guojia jiancha weiyuanhui) that would be placed under the guidance of the CCDI that would replace certain functions of the procuratorate. See Jianxiong Wu (吴健雄), Wo Guo Jiang Chengli Guojia Jiancha Weiyuanhui (我国将成立国家监察委 员会) [China Will Establish a State Supervisory Committee], Zhongguo Shehui Kexue Wang (中国社会科 学网) [CHINA SOCIAL SCIENCE NET] (2016), http://bbs.voc.com.cn/topic-7529366-1-1.html.
} 


\section{Regulatory Convergence}

Although the FCPA and the PRC anticorruption campaign originate out of vastly different contexts, they converge in the practice of compliance. As one partner of a U.S. law firm stated, "Every FCPA violation is a potential violation of PRC law."116 As a matter of conducting business in China, U.S. companies must adhere not only to the laws of their home country but also the country where they establish a foreign investment entity. These subsidiaries of U.S. MNCs are thus subject to PRC law, and, by extension, the PRC anticorruption campaign. U.S. MNCs must comply with both regulatory regimes, yet, for the most part, there is no one-stop shopping for legal services in China. Both U.S. law firms and PRC law firms face constraints - legal, market, and linguistic in assisting U.S. MNCs with their compliance programs. Further, the overlap in regulatory regimes also means that both the U.S. regulators and PRC regulators have crisscrossing jurisdiction over U.S. MNCs. This overlap creates opportunities for collaboration but is equally subject to the politics of U.S.-China relations. In this subsection, I explain the factors that lead to the convergence of anticorruption regulatory regimes in China across these jurisdictional fault lines within a fractious community of transnational lawyers.

As a result of the comingling of interests between regulators and private law firms, FPCA practice in China has experienced rapid growth and market diversification. Most lawyers I spoke to identified the recovery from the 2008 global financial crisis as the time when FCPA practice in China began to experience real growth. Up until 2009, it was peripheral to U.S. law firms and almost unheard of among PRC law firms. Whereas U.S. law firms had been particularly hit by the financial meltdown, and the increasing

\footnotetext{
${ }^{116}$ Interview, Shanghai, July 18, 2016.
} 
competitiveness of PRC firms has further decreased U.S. law firm profits, the FCPA is "one of the few bright spots" as one lawyer told me. ${ }^{117}$ "It's a revenue-generating law,",118 another lawyer said. A third lawyer gushed, "the U.S. government has generated more revenue from those few pages of the FCPA statute, in recent years, than most other corporate governance statutes combined." ${ }^{119}$ As a result, a fourth lawyer called FCPA practice a "gold rush." ${ }^{120}$ As mentioned, ${ }^{121}$ voluntary disclosure is not a requirement of the law; rather it is an effect of its enforcement. Lawyers were candid in identifying themselves as the main proponents of making FCPA compliance a core interest of their clients. By giving the client the option to self-report, the client has the prerogative as to whether to incur the costs of an internal investigation. A U.S. law partner admitted, "As service providers, we build hype."122

Yet fallout from an FCPA investigation is not just hype; there are real consequences for an MNC if the DOJ or SEC investigates them. In terms of number of enforcement actions, China has been a mainstay of DOJ and SEC regulation since 2008. Since that year, 28 out of 201 DOJ enforcement actions (fourteen percent) were against MNCs because of bribing officials in China, totaling $\$ 804.2$ million in fines ${ }^{123}$ (see Appendix 1). For that same period, the SEC has imposed penalties on MNCs for violations in 33 out of 110 cases (or, thirty percent) for a total of $\$ 1.02$ billion in fines ${ }^{124}$

\footnotetext{
${ }^{117}$ Interview, Shanghai, July 22, 2016.

${ }^{118}$ Interview, Shanghai, July 21, 2016.

${ }^{119}$ Interview, Beijing, July 22, 2016.

120 Telephone interview, Aug. 23, 2016.

${ }^{121}$ See supra text accompanying notes 74 and 75.

${ }^{122}$ Interview, Shanghai, July 21, 2016.

${ }^{123}$ Data generated from the official DOJ list of DPAs and NPAs. See U.S. Department of Justice, Related Enforcement Actions (2016), https://www.justice.gov/criminal-fraud/related-enforcement-actions.

${ }^{124}$ Data generated from the official SEC list of enforcements. See SEC Formations Actions: FCPA Cases, U.S. SECURITIES AND EXCHANGE COMMISSION (2016), https://www.sec.gov/spotlight/fcpa/fcpacases.shtml.
} 
(see Appendix 2). The amounts of fines for China-based FCPA violations have been substantial. In 2008, Siemen's AG had to pay combined penalties (i.e., imposed by both the DOJ and SEC) of $\$ 800$ million for violations of the FCPA in a number of countries, including China - the highest settlement amount in FCPA history. In 2010, Dailmer AG paid a total of $\$ 185$ million in criminal and civil charges for FCPA violations committed by three of its subsidiaries, one of which operated in China, and in 2014, Avon Products Inc. paid fines totaling $\$ 135$ million. ${ }^{125}$ The total amount of fines, criminal and civil, for settlements by MNCs for violations in China for the years 2008 to 2016 is $\$ 1.8$ billion. ${ }^{126}$ These cases are publicized in U.S. law firm memos and updates to clients as cautionary tales, thus contributing to FCPA hype. The total costs to MNCs under investigation go well beyond DOJ and SEC fines, including unreported fines, investigation costs, presettlement amounts, reputational harm, and shareholder derivative suits. ${ }^{127}$ Consequently, even as law firms push compliance, their clients face real potential costs for failing to do so.

Recently, compliance has taken on new urgency among MNCs in China with particular reference to the convergence of the FCPA and the PRC anticorruption drive. The particular case that marks this turning point is the 2013 GlaxoSmithKline (GSK) scandal that saw, for the first time, the PRC government fining a Western MNC for violations of PRC antibribery law, for a total of $\$ 490$ million. ${ }^{128}$ Prior to the GSK case,

\footnotetext{
${ }^{125}$ Calculation based on official DOJ and SEC statistics.

${ }^{126} \mathrm{Id}$.

${ }^{127}$ See Cottrell v. Duke, No. 15-1869 (8th Cir. 2016) (dismissing six derivative suits and consolidating them into one).

${ }^{128}$ The judgment came down from the Changsha City Intermediate Court on September 19, 2014, but has not been made public due to "business secrets." However, the facts of the case are known. On June 28, 2013, the Changsha City announced investigations into GSK executives for alleged economic crimes. On July 11, 2013, the Ministry of Public Security confirmed that it was investigating GSK executives for "serious economic crimes" (i.e., commercial bribery and embezzlement). Thereafter, the general manager
} 
MNCs sought to comply with local PRC law, but did not believe the authorities would necessarily enforce the laws. After GSK, nearly every lawyer I spoke to viewed the case as a watershed event in FCPA compliance in China specifically because it announced China as an emergent force in global anticorruption efforts and one that would apply steep penalties for violations of its antibribery laws. ${ }^{129}$ The GSK investigation was not an isolated incident but was part of a coordinated effort by the PRC authorities to discipline six other health-related companies at the time. Frequently, such investigations take the form of surreptitious data gathering through tapping phone lines and hacking e-mails for months, followed by a dawn raid during which data is removed from the MNC's offices. $^{130}$

Marking the convergence of the regimes, the GSK investigation had a cascade effect and triggered an FCPA investigation as well as an investigation under the U.K. Bribery Act of 2010 against the U.K. company. ${ }^{131}$ Among all lawyers I spoke to, each of GSK returned to China to cooperate with officials. After a ten-month probe, on May 14, 2014, official news outlets reported that the investigation was complete and the case would be transferred to the procuratorate. According to official accounts, GSK China had built bribery costs into its drug prices and ordered employees to bribe doctors to boost sales, resulting allegedly in billions of renminbi in sales. In addition to the fine, the general manager was given a three-year sentence that was suspended, and he was ordered to leave the country. See Guoyanwang Hangye Yanjiubu (国研网行业研究部) [National Study Web Professional Research Department], Gelansushike Shangye Huilu Shijian de Chengyin, Yingxiang ji Jianyi (葛兰素史克商业贿赂事件的成因, 影响及建议) [Contributing Factors, Influences, and Proposals Regarding the GSK Commercial Bribery Affair], Guoyanwang (国研网) [NATIONAL STUDY WEB] (2013), http://www.govinfo.so/news_info.php?id=20345.

${ }^{129}$ See Thomas R. Fox, GSK In CHINA: ANTI-Bribery ENForCEMENT GOES GlobAL (2015). Many industry insiders I spoke to cited the case as evidence that foreign companies face increasing regulatory pressure in Xi's China. See also AMERICAN CHAMBER OF COMMERCE, COMPLIANCE IN CHINA: ONGOING REGULATORY AND OPERATIONAL CHALLENGES (2016).

${ }^{130}$ See ZHONGGUO GONGSIFAWU YANJIUYUAN (中国公司法务研究院) [CHINA INSTITUTE OF CORPORATE LEGAL AFFAIRS] \& FANGDA LÜSHI SHIWUSUO (方达律师事务所) [FANGDA LAW FIRM], 2015-2016 ZHONGGUO FANSHANGYE HUILU DIAOYAN BAOGAO (2015-2016 年中国反商业贿赂调研报告) [REPORT ON ANTI-COMMERCIAL BRIBERY SURVEY AND STUDY, 2015-2016] 4 (2016) (showing that thirty percent of their respondents had been affected by dawn raids).

${ }^{131}$ As the U.S. does not recognize international double jeopardy, the preceding PRC criminal investigation does not bar the U.S. authorities from prosecuting under the FCPA. On September 30, 2016, the SEC fined GSK \$20 million, suggesting that the U.S. authorities took into consideration the prior PRC penalty. See Richard Cassin, GSK Pays SEC \$20 Million to Settle China FCPA Violations, FCPA BLOG (Sept. 30, 
reported that the anticorruption campaign has made their clients consider PRC antibribery laws more seriously and adjust their compliance programs accordingly. Such adaptions were common across the board but especially so among pharmaceutical and medical equipment companies, automobile companies, and luxury goods providers. In short, the globalization of corruption has caused jurisdictional overlap between the PRC and the United States (as well as other states), which, in turn, has increased the number of players in compliance. Before turning to how global corruption is changing the legal market for anticorruption, I first examine the issue of interregulatory coordination.

In recent years, there has been more cooperation between U.S. and PRC regulators on anticorruption, suggesting a nascent network, ${ }^{132}$ one based on mutual interest yet also prone to the vicissitudes of U.S.-China relations. ${ }^{133}$ Collaboration has resulted in a number of memoranda of understanding, including those under the U.S.China Joint Liaison Group on Law Enforcement Cooperation (JLG). ${ }^{134}$ As mentioned, one of the problems of the extraterritoriality of the FCPA is that it is difficult for U.S. law enforcement to collect evidence to investigate potential violations. Often, the United

2016), http://www.fcpablog.com/blog/2016/9/30/gsk-pays-sec-20-million-to-settle-china-fcpaviolations.html.

${ }^{132}$ See Margaret K. Lewis, Human Rights and the U.S.-China Relationship, 49 GEO. WASH. INT'L L. REV. (forthcoming) (arguing that bilateral cooperation can provide a pragmatic way for the U.S. to support human rights concerns in China).

${ }^{133}$ One feature of transnational governance is networks between regulators. See, e.g., Charles K. Whitehead, What's Your Sign? -International Norms, Signals, and Compliance, 27 Mich. J. InT'L L. 695 (2006); Pierre-Hugues Verdier, Transnational Regulatory Networks and Their Limits, 34 YALE J. INT'L L. 112 (2009).

${ }^{134}$ The JLG, established in 1997, was founded to address transnational criminal concerns. In 2015, the JLG founded the Anti-Corruption Working Group. See Bruce Ohr, Opening Remarks by Bruce Ohr, Associate Deputy Attorney General, U.S. Department of Justice, Joint Liaison Group on Law Enforcement Cooperation (JLG) Anti-Corruption Working Group. October 20, 2015 Beijing, China (Oct. 20, 2015), http://beijing.usembassy-china.org.cn/opening-remarks-associate-deputy-attorney-general-bruce-ohr.html (stating "we do not condone the selling by an official of any country of his or her office for personal gain, and we will do everything in our power to ensure that that official and his or her ill-gotten gains do not find safe haven in the United States"). During a 2015 visit to the White House by Xi Jinping, President Obama and $\mathrm{Xi}$ agreed to increase interagency cooperation to fight corruption. See PRC Ministry of Foreign Affairs, Outcome List of President Xi Jinping's State Visit to the United States, XINHUA (Sept. 26, 2015), http://www.chinadaily.com.cn/world/2015xivisitus/2015-09/26/content_21988239_4.htm. 
States must rely on local law enforcement. Up until recently, the PRC authorities have been reluctant to share information with the DOJ and SEC. The flight of "economic fugitives" to the United States, however, has created incentives for the Chinese to seek U.S. help in their repatriation. According to FCPA lawyers, the U.S. and PRC governments have exchanged information about PRC officials residing in the United States who were alleged to have laundered money.

In what has been called "Operation Foxhunt," a number of high-profile arrests of Chinese nationals in the United States have followed, such as the case of Zhao Shilan. ${ }^{135}$ In return for repatriating PRC nationals suspected of graft, the U.S. government has gained access to evidence in China. The Federal Bureau of Investigation has met with counterparts in the Ministry of Public Security to coordinate sting operations and use local PRC enforcement to gather information about U.S. MNCs. ${ }^{136}$ Such interagency investigations are equally prone to being derailed however, and many PRC lawyers I interviewed emphasized the unwillingness of the PRC government to share resources with the United States. ${ }^{137}$ In addition to formal collaboration and information sharing, regulators from the United States and PRC “cherry pick” each other's enforcements by watching for violations under one anticorruption regime and then bring an investigation

\footnotetext{
${ }^{135}$ Zhao was married to Qiao Jianjun, a former official who fled China allegedly with illicit assets. Charged with money laundering and immigration fraud under the EB-5 program, their investigation featured coordination between the U.S. Immigration and Customs Enforcement, Homeland Security Investigations, Internal Revenue Service, U.S. Citizenship and Immigration Services, and the Supreme People's Procuratorate and the Ministry of Public Security. See, e.g., The U.S. Attorney's Office in the Cent. Dist. of Cal., Fugitive Chinese Official and Former Wife Named in Grand Jury Indictment Charging Immigration Fraud and Money Laundering (Mar. 17, 2015), https://www.justice.gov/usao-cdca/pr/fugitive-chineseofficial-and-former-wife-named-grand-jury-indictment-charging. According to one Beijing judge I spoke to, the Federal Bureau of Investigation and the overseas office of the CCDI, based in the PRC embassy in Washington, D.C., also worked together on this case. Interview, Beijing, Aug. 13, 2016.

${ }^{136}$ Interview, New York City, June 22, 2016.

${ }^{137}$ One forensics specialist who was involved in the GSK case told me that in the aftermath of the GSK scandal, "the SFO [Serious Fraud Office] came and wanted the PRC to share evidence with them. I think seventy percent of the evidence was coerced and they didn't share anything. The Brits returned emptyhanded.” Interview, Shanghai, July 22, 2016.
} 
under their regime, as in the example of the GSK case. ${ }^{138}$ Lastly, if a public U.S.

company faces PRC regulatory actions, then there may be disclosure obligations on the U.S. side. $^{139}$

Yet because of the nature of compliance, the immediate enforcers of anticorruption norms are not the regulators, but rather MNCs' lawyers because they advise their clients on the various risks associated with voluntary disclosure, advice that responds to not just formal law and regulation but also the political climate. The actual work of compliance is thus partially privatized, making FCPA enforcement an exercise in neoliberal governance where private actors work alongside government regulators. ${ }^{140}$ Almost every lawyer I spoke to said that the PRC anticorruption drive was "good for [FCPA] business," meaning that clients were taking compliance more seriously. Law firms' compliance practices thus respond to heightened regulation; lawyers are keenly aware of changes in regulatory policies. U.S. law firms aggressively hire former prosecutors from the DOJ, for example, and in recent years, PRC law firms are hiring former criminal court judges and procurators. The boundaries between law firms and regulators are thus porous; skill sets are transferable between the professions of regulator and lawyer. Equally, coordination is possible between regulators across jurisdictions, and even U.S. and PRC law firms may work together on an FCPA matter. Yet the transnational community is not simply characterized by coordination. It is just as much

\footnotetext{
${ }^{138}$ See supra text accompanying note 128.

139 See 17 C.F.R. $\S 229.103$ (2011).

${ }^{140}$ See Gunther Handl et al., Beyond TERritoriality: Transnational LEGAl Authority IN AN AGE OF GLOBALIZATION (2012) (discussing the various forms of coordination in a multiple-layered normative system).
} 
formed by strained interagency ties and competition between U.S. and PRC law firms. ${ }^{141}$ In the following section, I explain how market preferences have given the community of lawyers a certain shape, one oriented toward what I call bicultural lawyers.

\section{The Bicultural Lawyer}

The cross-border practice of the FCPA has been influenced by not only the U.S. government's efforts to create an extraterritorial compliance regime, and one that overlaps with the PRC anticorruption regime, but also the particularities of lawyering in China. Since the business of FCPA compliance has increased in China following the GSK case (again, a PRC legal enforcement action), U.S. law firms nonetheless face hurdles in conducting compliance work in China. These include limits on legal practice and the factors of linguistic and cultural fluency. The convergence of the anticorruption regimes has also allowed PRC law firms to practice the FCPA. These factors have shaped the market such that both U.S. law firms and PRC law firms, which traditionally have been populated by U.S. nationals with U.S. bar licenses and PRC nationals with PRC bar licenses, respectively, are increasingly "coming to the middle." The result is that both U.S. law firms and PRC law firms have singly or, increasingly, dually qualified bilingual lawyers who understand both FCPA and PRC compliance. ${ }^{142}$

\footnotetext{
${ }^{141}$ Sida Liu, Globalization as Boundary-Blurring: International and Local Law Firms in China's Corporate Law Market, 42 LAW \& SOC'Y REV. 771, 772 (2008) (noting that with the increasing blurring between U.S. and PRC legal practice in China, there are a number of "turf wars").

${ }^{142}$ There are a number of permutations of those lawyers who practice FCPA law: (1) U.S. nationals who are U.S.-qualified working at U.S. law firms or a U.S. company, (2) PRC nationals who are either PRCqualified or dually qualified working in a U.S. law firm or in a U.S. company, (3) PRC nationals who are U.S.-qualified working in a U.S. law firm or U.S. company, and (4) PRC nationals who are PRC-qualified working in a PRC law firm. Categories (2) and (3) represent dually qualified lawyers who are increasing in number.
} 
In this section, I assess how these different lawyers conduct FCPA compliance, which consists of a number of tasks, namely, internal investigations, compliance training, and due diligence. Internal investigations, begun with an allegation of bribery, are conducted by lawyers for MNC clients in advance of a potential investigation by the DOJ or SEC (see Figure 1). Compliance training is a reoccurring practice done at the behest of MNCs to ensure that their overseas employees are aware of applicable U.S. and PRC rules for expenses, gifts, and travel and entertainment. Due diligence is a vital component of most corporate transactions, such as when a U.S. company acquires a PRC company and needs to assess FCPA risks, particularly in regard to prior corruption by the target company's management and employees. Among these aspects of FCPA practice, while due diligence in advance of a merger or acquisition is increasing, in part because of heightened scrutiny of PRC businesses pursuant to the anticorruption drive, internal investigations comprise the majority of work lawyers do in this area. ${ }^{143}$ I thus focus on the investigation with an emphasis on the issue of determining standards for what qualifies as corruption. I argue that the nature of the standard enforcer influences the standard(s) selected and to whom it or they are applied.

[insert Figure 1 here]

\section{U.S. Law Firms}

\footnotetext{
${ }^{143}$ The proportion of work varies both through time and according to whether a lawyer is in-house or works for a private firm. As late as 2012, compliance training was the main focus of law firms. However, in recent years, work on internal investigations has far outpaced that of compliance training. An in-house lawyer may spend more time on training than a lawyer working for a law firm.
} 
During the period of growth for FCPA practice in China (roughly, 2008 to 2016), most practice groups based in China have been led by a U.S. national who was trained in the United States and joined the bar in the United States. Most of the major U.S. law firms with operations in China ${ }^{144}$ that have an FCPA practice group have entered the market in this fashion. ${ }^{145}$ In addition to this feature, there are a number of different models among these practice groups. Some U.S. law firms have a global practice with a division of labor that allocates much of the high-level decision making about a case to lawyers in the Washington, D.C., or New York offices, as these lawyers are closest to changes in regulatory policy. The China presence is important to demonstrate, as one young associate in a U.S. law office put it, "in-depth understanding of the local regulatory environment, ${ }^{, 146}$ although central offices in the United States (D.C. or New York City) may continue to steer the internal investigation and not delegate high-level decisions to the China offices. As a partner of a law office in Shanghai admitted, "to be coarse, it all depends on how much the HQ trusts the China offices." "147

The constraints of legal practice and linguistic and cultural fluency are particularly acute for U.S. firms. All foreign-licensed lawyers in China face restrictions on their practice; chief among them, they cannot opine on matters of PRC law, and they cannot represent their clients in PRC courts. ${ }^{148}$ To address these limitations, U.S. law

\footnotetext{
${ }^{144}$ See Rachel E. Stern \& Su Li, The Outpost Office: How International Law Firms Approach the China Market, 41 LAW \& SOC. INQUIRY 184, 185 (2015) (finding that there were 174 international law firms in China, including but not exclusive to U.S. ones, registered with the Ministry of Justice in 2012).

${ }^{145}$ The practice may be called, variously, "antibribery," "regulatory compliance," "compliance" or be part of the litigation or white-collar crime practice groups.

${ }^{146}$ Telephone interview, Aug. 11, 2016.

${ }^{147}$ Interview, Shanghai, July 22, 2016.

${ }^{148}$ Rather, foreign lawyers are able only to provide information on China's legal environment. See Waiguo Lüshi Shiwusuo Zhuhua Daibiao Jigou Guanli Tiaoli (外国律师事务所驻华代表机构管理条例)

[Regulations on Representative Offices of Foreign Law Firms in China], art. 15, adopted at the Fifty-First
} 
firms hire local counsel, although, U.S. lawyers may be able to conduct most of the legal analysis and ask a PRC law firm to bless their analysis by providing a legal opinion. One controversial issue is whether U.S. lawyers have the right to conduct internal investigations in China. This point raised the most intense disagreement between U.S. and PRC lawyers. U.S. lawyers take the view that the FCPA, as a U.S. law with long-arm jurisdiction, empowers them to conduct investigations of their clients who are mainly U.S. MNCs. PRC lawyers contended that investigation is done as part of litigation, which they understand as the practice of law. "It's a sovereignty issue," one claimed. "They are not licensed here," he continued. ${ }^{149}$ PRC lawyers can and do make such assertions about foreign lawyers in other areas of law, but compliance is a lightning rod for such contests because it is so lucrative.

This issue was addressed, in part, in the GSK case. In the course of handling its internal investigation, GSK had hired a private investigator, a British national, Peter Humphrey, to collect information regarding activities of a whistle blower and a sex tape of the general manager that was used to blackmail him. ${ }^{150}$ The private investigator and his Chinese wife were arrested on charges of violating article 253 of the PRC Criminal Law regarding unlawful acquisition of citizens' personal information and were handed a sentence of two years' imprisonment. ${ }^{151}$ A member of a risk management firm told me, "the PSB [Public Security Bureau] does not like [foreigners using the term] diaocha (survey). We use fenxi (analyze), yanjiu (research) et cetera, but never diaocha. Peter

Meeting of the State Council, Dec. 19, 2001, promulgated by the Decree No. 338 of the State Council, and effective Jan. 1, 2002.

${ }^{149}$ Interview, Shanghai, July 19, 2016.

${ }^{150}$ In my interviews with lawyers who were involved with the GSK case, they frequently said that the case was motivated by political reasons, namely, a government relations director in the China subsidiary held a grudge against the company's general manager and collected evidence of illicit acts against him. ${ }^{151}$ See Donald Clarke, Don't Ask, Don't Sell: The Criminalization of Business Information-Gathering in China and the Case of Peter Humphrey, 33 UCLA PAC. BASIN L.J. 109, 111 (2016). 
Humphrey took phone records and bank records-you're not supposed to do this, so he violated the law."152 Some PRC lawyers I met saw this as setting a precedent for foreign lawyers, but U.S. lawyers disagreed, distinguishing the treatment of private investigators from foreign lawyers under PRC law. Nonetheless, PRC employees of U.S. subsidiaries have used this argument in their defense when subjected to investigations by their employees. ${ }^{153}$ Restrictions on internal investigations, especially if those investigations include collecting data on PRC citizens, limit the type of evidence lawyers in U.S. law firms can collect. This constraint, coupled with data privacy laws and state secrecy laws that are also evolving in the course of the anticorruption campaign, decrease the scope of lawyers' investigations by preventing certain documents from leaving the country or prohibiting disclosure. ${ }^{154} \mathrm{~A}$ few law firms work around some of these limitations by, for example, establishing partnerships with PRC law firms and founding data centers that allow them to expand their investigatory capabilities. ${ }^{155}$

Restrictions on conducting investigations dovetail with another constraint on U.S. lawyers engaged in FCPA compliance-language and culture. Internal investigations in China inevitably entail reviewing documents, e-mails, text messages, and other forms of communication and writing in the Chinese language. Document review is the most laborand time-consuming aspect of internal investigations, and can last several months for one

\footnotetext{
${ }^{152}$ Interview, Shanghai, July 22, 2016.

${ }^{153}$ One lawyer said that in the course of an investigation, a PRC employee hired a PRC lawyer to make this argument and ultimately the company did not pursue its investigation of the employee. Telephone interview, Aug. 18, 2016.

${ }^{154}$ See Zhonghua Renmin Gongheguo Baoshou Guojia Mimifa (中华人民共和国保守国家秘密法) [Law of the PRC on Guarding State Secrets], adopted at the Third Meeting of the Standing Committee of the Seventh NPC, Sept. 5, 1988 and promulgated by Order No. 6 of the President of the PRC, Sept, 5, 1988, art. 6 .

${ }^{155}$ See MWE China Law Offices and McDermott Expand China's First Law Firm Discovery Center, MCDERMOTT WILL \& EMORY (2016), https://www.mwe.com/en/press-room/2016/05/mwe-china-law-andmwe-expand (describing a discovery platform within China, operated by PRC-qualified lawyers, within a PRC law firm that has a "strategic alliance" with a Chicago-based firm).
} 
case, involving associates in multiple offices coordinating their search through a data room. Lawyers use e-discovery software to generate new key words, and associates "tag" documents as "responsive" or "nonresponsive," accordingly. Local knowledge is helpful in designing key word searches as terms, names, and processes can be specific to industries and regions. The lawyers expand or refine the search, and associates may review upwards to 20,000 documents in a single day. Only a portion of those "responsive" is then sent up to senior associates for analysis. While some U.S. law firms contract with PRC law firms to conduct document review, many clients prefer to minimize the number of parties exposed to their internal documents, and thus U.S. law firms conduct the due diligence internally.

In addition to the primacy of Chinese language-proficient associates for document review, native Chinese-speaking associates were essential for interviews with PRC employees of U.S. subsidiaries. Partners bemoaned the phenomenon of U.S. lawyers, who lacked local cultural knowledge and thus failed to collect sufficient testimony, traveling to Beijing or Shanghai to conduct interviews. Knowledge of Chinese, and sometimes specific dialects, as well as familiarity with Chinese social customs of truthtelling or lying, were basic skills needed to show a good faith effort in interviewing employees suspected of violating the FCPA. ${ }^{156}$

A typical interview scene was the following: the American partner (usually, senior, white, and male) would sit next to a Chinese associate (junior and often female) across from a Chinese employee (normally, senior and male) of a Chinese subsidiary of a U.S. company. The American partner, especially if he had litigation experience, would ask questions in English with an assertive if not aggressive tone. The Chinese associate

${ }^{156}$ Interviews, Beijing, July 14, 2016 and Shanghai, July 22, 2016. 
would then translate the questions to the Chinese employee but would sometimes calibrate the tone for speaking to a senior male, making it more deferential (although the partner's tone was apparent to the employee). ${ }^{157}$ The employee would respond in a tone suitable for a senior male speaking to a junior female, and then the Chinese associate would adjust that message again to address the American partner. The Chinese associate, embedded in dual hierarchies, is the interpretive lynchpin of these interviews, and the transnational community of anticorruption lawyers is composed of such dexterous speech acts. Rather than being subordinated to the Chinese and American male authority, however, often the Chinese associate constructs the understanding of a corrupt act through such triangulations. One female American partner acknowledged this saying, Interpretation is huge. Often they [the MNC] flies in white guys and after some period of time, they leave the interview room saying, 'these interviewees are not cooperating.' There is a lot of nuance in the language that they cannot get. They fail to pin the employee down, and the interview fails. The interpreter must be aware of terms of art, how expressions can be literal or non-literal . . I have a female associate who is very junior and is physically small and looks young. She is not from Shanghai but can speak Shanghainese. She was interviewing two employees once and they began speaking in Shanghainese in front of her thinking she was an outsider [waidiren]. She took all this in, and then after a while, started responding in Shanghainese. That changed the tenor of the interview. ${ }^{158}$

\footnotetext{
${ }^{157}$ Another variant was for the client to be represented in the interview by the law firm partner, an associate, and a professional translator. Under such an arrangement, the associate is freed to focus on analysis but nonetheless plays a pivotal role as cultural intermediary and occasionally directly intervenes in translation.

${ }^{158}$ Interview, Shanghai, July 22, 2016.
} 
In other firms, the relationship between associate and partner may not be as hierarchical, and instead of a white male partner from the United States, it may be a female Chinese associate who flies from one office to another to conduct interviews. Indeed, of the total number of PRC nationals who have matriculated at J.D. programs in U.S. law schools from 2012 to 2016, sixty-two percent were female. ${ }^{159}$ It appears some of these women obtain employment in U.S. law firms and that regulatory compliance may be one practice area where women attain positions of leadership. ${ }^{160}$ Of my random sample of interviewees, the majority of lawyers (associates and partners) working in the FCPA field were women. In interviews, female lawyers drew more attention to the crucial role of interpersonal "dynamics." These may change from a stalled English-toChinese translation (via a professional translator) to one in which the Chinese associate speaks Mandarin directly to the employee, after which, as one London-based female lawyer said, “the employee's demeanor becomes more cooperative [even though] he may still be lying to me."161

Chinese associates, female and male, thus have a significant capacity to glean information. They do so through their attention to "context and tone," as one Hong Kong-based associate said, that differentiates whether a term is "derogatory" or "halfjoking" and ultimately the key to understanding "business norms." ${ }^{162}$ Some U.S. partners

\footnotetext{
${ }^{159}$ Statistic calculated from data obtained from the Law School Admissions Council.

${ }^{160}$ But see Fiona M. Kay et al., Undermining Gender Equality: Female Attrition from Private Law Practice, 50 LAW \& SOC'Y REV. 766 (2016) (finding a high rate of attrition among female lawyers in law firms); Chunyan Zheng et al., The Elastic Ceiling: Gender and Professional Career in Chinese Courts, 51 LAW \& SOC'Y REV. (forthcoming) (showing that the percentage of female lawyers in law firms is lower than the percentage of female law students, arguing that women face a glass ceiling in legal careers).

${ }^{161}$ Telephone interview, Nov. 14, 2016.

${ }^{162} I d$. Likewise, on the front end of an investigation, bicultural lawyers attune the keywords for document review. As one Shanghai-based lawyer said, "you have to know how people use language," citing the example of the more colloquial term youshui (benefit) over the formal legal term huilu (bribe), the former of which is more likely to be found in employee correspondence. Telephone interview, Nov. 21, 2016.
} 
told me that they do not allow any American nonnative Chinese speaker in the room and only have a Chinese associate in the room representing the company. Once the Chinese associate acquires the information, it is then passed on to the U.S. partners who include this in their response to the client as to whether they should disclose the behavior to U.S. regulators or not. In short, the role of the bicultural lawyer provides a comparative advantage on the outcome of the investigation by providing the partner with the relevant information to advise on disclosure or its alternatives. As such, the bicultural lawyer is the cutting edge of self-discipline.

The fact that U.S. law firms are Chinese language proficient in conducting FCPA investigations does not change their tendency to apply the standards of the FCPA (i.e., "anything of value") rather than the monetary thresholds in the PRC antibribery laws. Many U.S. lawyers cited the local law defense in the FCPA, ${ }^{163}$ but because PRC law does not permit bribery, their inquiry into the applicability of PRC legal standards for bribery stopped there. A Chinese American partner in a U.S. law firm based in Shanghai said that beyond an analysis of PRC state secrecy law, they do not consider PRC law. One associate, a Chinese American working in Shanghai for a U.S. law firm, said flatly, "I don’t know anything about PRC law."164

In other law firms, associates may conduct research on PRC laws, for example, the 1993 rule specifying that a gift over 200 yuan must be "passed up" and may reference these in a memo to a client, but the lawyers rarely analyze PRC laws. Only one partner at a U.S. law firm said the internal CCP rules would also be referenced saying, "They provide clearer guidance on what officials can and cannot do," and as the client may be

\footnotetext{
16315 U.S.C. $\S \S 78 d d-1(c)(1), 78 d d-2(c)(1), 78 d d-3(c)(1)(2012)$.

164 Telephone interview, Aug. 11, 2016.
} 
interacting with officials or a state-owned enterprise, they should consider the CCP rules in their compliance. ${ }^{165}$ For the most part, rather than use the PRC monetary thresholds, lawyers in U.S. law firms used a variety of standards to gauge whether the DOJ would consider a gift to qualify as "anything of value," including using DPAs and NPAs as precedents; considering pronouncements of the DOJ in terms of trends for future enforcement; checking the U.S. Sentencing Guidelines, ${ }^{166}$ or, most commonly, beginning with the nature of the allegation and conservatively collecting evidence. The picture then is one of lack of uniformity in addressing the question of what qualifies as "anything of value. $" 167$

Unlike the 1980s, when U.S. law firms were establishing themselves in China, the current trend is not just to provide legal services to foreign investors or U.S. MNCs, but also to provide advice to PRC companies that are investing overseas, buying U.S. companies, or setting up their own subsidiaries, all of which expose them to FCPA compliance. ${ }^{168}$ The changing nature of clients requires U.S. law firms to analyze PRC law and even Party rules in addition to the FCPA and creates demand for Chinese-language associates who can conduct such analysis. As one PRC national working in a U.S law firm said, the creation of subsidiaries in the United States by PRC companies has “opened up a whole new field," particularly since 2005 when outbound work began increasing. ${ }^{169}$ Consequently, many junior associates in recent years have tended to be either Chinese Americans fluent in Chinese or PRC nationals trained in China and

\footnotetext{
${ }^{165}$ Telephone interview, Aug. 23, 2016.

${ }^{166}$ The DOJ uses the U.S. Sentencing Guidelines Manual section 1A1.1 (2011) to calculate penalties for violations of the FCPA.

${ }^{167}$ Surprisingly, the legislative history of the FCPA does not contemplate the problem of "anything of value," which would have been resolved if it had required consideration of local law to define the element. ${ }^{168}$ See Mark Wu, The 'China, Inc.' Challenge to Global Trade Governance, 57 HARV. InT'L L.J. 1001 (2016).

${ }^{169}$ Interview, Beijing, July 15, 2016.
} 
possibly the United States. Practice groups with bilingual associates were more likely to integrate CCDI rules into their analysis, even if the client was a U.S. and not PRC company. The rationale given was that the lawyer had to advise the U.S. client about restrictions on the receiving side pursuant to PRC law and CCDI rules. ${ }^{170}$ In summary, the diversification of the transnational community that increasingly includes PRC MNCs has created market demands for bicultural lawyers who are proficient in the investigatory methods and legal analysis of the converging anticorruption regimes.

\section{PRC Law Firms}

The PRC anticorruption movement has expanded the transnational community of anticorruption lawyers by creating opportunities for PRC law firms to enter the compliance market and occupy space from which U.S. law firms are excluded or are in an inferior position due to the restrictions on their practice and lack of linguistic and cultural fluency. PRC law firms are in a growth phase. By 2014, the country added 1,600 law firms for a total of $22,200 .{ }^{171}$ Following the increasing sophistication of PRC law firms, they have expanded their practice areas. Some of the largest firms, including Zhonglun, Jun He, and Fangda, all have compliance practice (hegui diaocha) groups. PRC law firms are both hired directly by U.S. MNCs or indirectly by their U.S. law firms and often conduct document review.

\footnotetext{
${ }^{170}$ This is particularly so if the case involves a state-owned enterprise. Many of these are known as "yangqi," have developed the practice of signing "sunshine agreements" (yanguan xieyi) with their business partners, including U.S. MNCs. These agreements are considered codes of conduct and contain anticorruption representations, which U.S. MNCs must make.

${ }^{171}$ Sifabu (司法部) [Ministry of Justice], 2014 Nian Quanguo Lüshi Gongzuo Tongji Jiben Shuju (2014 年 全国律师工作统计基本数据) [Basic Statistical Figures for the Work of Lawyers for the Whole Nation in the Year 2014] (Apr. 16, 2015), http://www.xjsft.gov.cn/sfxz/sfdt/2015/218804.htm. See also Sida Liu \& Hongqi Wu, The Ecology of Organizational Growth: Chinese Law Firms in the Age of Globalization, 122 AM. J. SOCIO. 1, 3 (2016) (stating "the speed and magnitude of law firm growth in this emerging market in the early 21 st century are unprecedented in the global history of the legal profession").
} 
Significantly, there was no domestic antibribery practice before the FCPA took root around 2008. ${ }^{172}$ The 2010 Rio Tinto case, ${ }^{173}$ which saw four PRC employees of an Australian mining company jailed for bribery and stealing "commercial secrets," was the beginning of PRC law firms' representing foreign clients in bribery cases. ${ }^{174}$ Ninety percent of their clients of the largest PRC law firm with an active compliance practice are foreign. The presence of U.S. clients does not automatically mean that PRC law firms can practice FCPA law, just as U.S. firms' accepting PRC MNCs as clients does not confer on them the authority to practice PRC law. However, both sides do precisely that. PRC law firms increasingly hire PRC nationals who have U.S. law credentials, and thus, they argue, their right to practice U.S. law follows from retaining these lawyers.

There is an increasing trend for young PRC lawyers to obtain a law degree in the United States that allows them to sit for a state bar exam and become licensed in the United States. ${ }^{175}$ According to the Law School Admissions Council, as of 2011, China has produced the second largest number of foreign matriculants to U.S. law schools after

\footnotetext{
${ }^{172}$ The reasons for this are several, including, cultural factors. Companies often send their "public relations" staff members to deal with governmental investigators rather than lawyers, since the former are considered more adept at relationship-building. Also, procedurally, there is no settlement under PRC law as there is under U.S. law, and hence there is no incentive to conduct an internal investigation. See Li \& Deng supra note 107, at 16 (2016) (explaining the plea bargaining process in PRC criminal justice). Finally, whereas PRC criminal law includes both individual crimes and work unit crimes (danwei fanzui), in practice, courts strongly prefer individual criminal liability.

${ }^{173}$ The judgment came down from the Shanghai City Intermediate Court on March 29, 2010, but has not been made public due to "business secrets." See Renmin Wang (人民网) [People's Net], Shanghai Shi Diyi Zhongji Renmin Fayuan Dui Li Ta An Zuochu Yishen Panjue (上海市第一中级人民法院对力拓作出一审 判决) [Shanghai City Intermediate Court Hands Down a Judgment in the First Instance on the Li Tan Case] (Mar. 30, 2010), http://news.sohu.com/20100330/n271193962.shtml.

${ }^{174}$ Interview, Shanghai, July 19, 2016.

${ }^{175}$ Mindie Lazarus-Black \& Julie Globokar, Foreign Attorneys in US LL.M Programs: Who's In, Who's Out, and Who They Are, 22 IND. J. Global Legal Stud. 3 (2015); Carole Silver, Getting Real About Globalization and Legal Education: Potential and Perspectives for the U.S., STAN. L. \& POL'Y Rev. 457 (2013); Carole Silver, States Side Story: "I Like to Be in America:" Career Paths of International LLM Students, 80 FORDHAM L. REV. 2383 (2012). On the education and career paths of PRC lawyers, see Liu supra note 141 at $789-95$.
} 
Canada. ${ }^{176}$ Whereas in the 1990 s and first decade of the 2000 s, the LL.M. was the degree of choice for would-be U.S.-licensed Chinese lawyers, the J.D., a weightier degree, is frequently the sought-after degree in recent years. From 2011 to 2015, the number of matriculants at J.D. programs who were U.S. citizens dropped by $19.5 \%$; the number of PRC nationals, over that same period, increased by $1.5 \% .{ }^{177}$ In the past, the path for a Chinese graduate was to work in a prestigious U.S. law firm for several years after obtaining an LL.B. degree from a PRC university, ${ }^{178}$ then study for an LL.M. degree in the United States for one year (an educational degree paid for by the U.S. firm), and lastly return to work with a pay raise. Nowadays, Chinese graduates are obtaining a J.D. in the United States after obtaining their undergraduate degrees in China (or the United States), and returning to China with more employment options.

While working in a U.S. law firm, Chinese lawyers feel the double-edged sword of regulation of foreign law firms in China. On the one hand, due to PRC-imposed restrictions, they must suspend their PRC law license, but also due to law firm-imposed limitations, they frequently encounter glass ceilings in making partner. When I worked for a law firm in Beijing, the "China advisors" (their title had to be other than "lawyer") quietly complained about such restrictions. While the salary for associate-level lawyers in the top PRC law firms is still not commensurate with salary at U.S. law firms, Chinese lawyers opting to work for a PRC firm do not face such constraints and can proceed along the partner track more quickly. In addition, many young Chinese lawyers start their

\footnotetext{
${ }^{176}$ See Law School Admissions Council, All Term Applicants, Admitted Applicants \& Matriculants to ABAApproved Law Schools by Country of Citizenship (2015), http://www.lsac.org/lsacresources/data/bycountry-of-citizenship.

${ }^{177}$ Statistics calculated from data provided by the Law School Admissions Council; data for LLM programs is not available.

${ }^{178}$ Matthew S. Erie, Legal Education Reform in China Through U.S.-Inspired Transplants, 59 J. LEGAL EDUC. 60 (2009) (explaining the reform of PRC law degrees in light of globalization).
} 
careers in a U.S. law firm, receive training for several years, and then leave for a PRC firm where they could make partner. ${ }^{179}$ Also, they would bring clients to the PRC law firm.

As a result of the hybrid background of their lawyers, PRC law firms can offer both foreign clients, including U.S. MNCs, and globally expanding Chinese MNCs and state-owned enterprises the best of both worlds. They offer legal analysis against the background of deep understanding of the Chinese regulatory environment, including its commercial, cultural, and political dimensions. As one PRC national with a U.S. J.D. working for a PRC law firm stated, "we want to give clients the full solution." ${ }^{, 180}$ In parallel with the trend of U.S. law firms to hire former DOJ prosecutors, PRC law firms also hire former procurators and judges. They provide insights as to the procurators' investigation process and also the reasoning of judge's decisions. One associate at a PRC law firm who had fifteen years of experience as a procurator stated that only because of his experience could he understand the critical question of the "enforcement of law" (zhifa). He did so by understanding the reasoning in the interpretations of the Supreme People's Court and Supreme People's Procuratorate, and the ways that judges apply legal analysis from previous cases. ${ }^{181}$ Moreover, former procurators and judges maintain ties with former colleagues that allows them to glean insights as to decision making that may not be apparent from published documents. These existing relationships deepen the PRC lawyers' understanding of regulators' approaches to compliance.

\footnotetext{
${ }^{179}$ Unlike the situation whereby PRC lawyers must suspend their PRC license to practice in a U.S. law firm, Chinese J.D. holders can retain their U.S. bar license while working for a PRC law firm.

${ }^{180}$ Interview, Beijing, Aug. 10, 2016.

${ }^{181} \mathrm{Id}$.
} 
Bicultural lawyers in PRC law firms advise their clients on not just potential violations of PRC law, but also PRC law and CCP rules, more so than their U.S. law firm peers. If the client is a U.S. MNC, PRC lawyers reason they must be advised on the limits imposed on officials to receive gifts. Their analysis proceeds by comparing the FCPA to PRC law and the internal rules of the CCP. While the CCP rules apply only to officials, sometimes the bribe giver will be approached by the CCDI to provide testimony as to an investigation against an official. In the course of negotiations with the bribe giver, the CCDI may threaten to make the bribe public, an act that may trigger a DOJ investigation if the act likewise violated the FCPA. As the standards for offering and receiving gifts under CCDI-enforced rules (e.g., the 1993 rule) are lower than those of the FCPA (e.g., a 200 yuan gift may not violate the FCPA), the PRC law firm will advise the client company to adopt the most conservative approach and follow the PRC rules. Consequently, the norms of the Party may influence the behavior of U.S. MNCs in a process of the "globalization" of the anticorruption drive. The expansive jurisdiction of $\mathrm{CCP}$ rules is a result of their enforcement primarily by bicultural lawyers and secondarily by PRC regulators, in this case the CCDI. Thus, who enforces standards of compliance influences the outcomes of which standards are enforced against whom.

Biculturalism is becoming the new normal in both U.S. and PRC law firms in China, and applies not only to FCPA work but also other areas of cross-border legal practice, including foreign direct investment, initial public offering, mergers and acquisitions, private equity and venture capital, and capital markets. The same market forces are pushing firms toward this common direction. FCPA practice, however, highlights the characteristics of transnational law discussed in this Article because it is 
one of the few litigation-driven practices in which U.S. lawyers engage within the PRC. Thus, the question of the permissibility of conducting investigations under PRC law, the application of standards, and, more centrally, the problem of self-discipline are all accentuated at the overlap of multiple anticorruption regimes.

\section{Conclusion}

This Article has argued that lawyers engaged in FCPA work form a kind of community, united by their specialized knowledge and skill sets, and yet one that is internally fractious given that, in their particular "ecology,", 182 U.S. and PRC law firms compete for clients. While U.S. and PRC regulators and lawyers are concerned with creating an "order," as shared norms that orient behavior, ${ }^{183}$ in this case, proper conduct by MNC employees with regard to the company's funds, the applicable standards that construct that order are refracted through the position of members in the transnational community. This community is formed by specific market preferences. Lawyers' employment in a U.S. or PRC law firm, their legal credentials and bar membership, as well as their language proficiencies, cultural intimacies, and even gender, can have outcomes on which standards they apply and to which kinds of clients.

This Article focuses on transnational communities of lawyers to bring agency back into discussions of transnational law. ${ }^{184}$ Yet it does so recognizing that agency does

\footnotetext{
${ }^{182}$ See Liu \& Wu supra note 170, at 5 (using the ecological theory of organizational growth to examine law firms' interactions in China through competition, accommodation, and assimilation).

${ }^{183}$ See Halliday \& Schaffer supra note 16 at 7, 8 (noting "considerable contestation regarding the appropriate substantive rules and monitoring organizations in light of alternative constructions of a problem and diagnoses of its causes ...").

${ }^{184}$ See also Tim Bartley, Transnational Governance as the Layering of Rules: Intersections of Public and Private Standards, 12 TheORETICAL InQUIRIES IN L. 518 (2011); Sebastian Botzem \& Sigrid Quack, Contested Rules and Shifting Boundaries: International Standard-Setting in Accounting, in TRANSNATIONAL GOVERnANCE: InstitutionAl DynAmics of REGUlation (Marie-Laure Djelic \&
} 
not equal radical autonomy, and, indeed, a Chinese anticorruption regime can discipline corporations through corporate law firms, and internal CCP rules may affect the behavior of U.S. MNCs. From the standpoint of lawyering, the layeredness of standards does not inherently present a problem, yet the very qualitative difference in the standards crossborder lawyers assess in the anticorruption field is striking-legal and ethical, capitalist and socialist, neoliberal and Leninist. The emergence of bicultural lawyers, who look to relevant PRC law and CCP rules to provide bright-line standards as to what constitutes "anything of value," pursuant to the language of the FCPA, suggests that transnational law may operate just as much through local law, campaigns, and politicized ethics just as much as it does formal legal instruments.

Kerstin Sahlin-Andersson eds., 2006); Leonhard Dobusch \& Sigrid Quack, Epistemic Communities and Social Movements: Transnational Dynamics in the Case of Creative Commons, in TRANSNATIONAL COMMUnities: Shaping Global ECONOMIC GovernAnCE (Marie-Laure Djelic \& Sigrid Quack eds., 2010). 
Table 1. List of Abbreviations.

\begin{tabular}{|l|l|}
\hline AUCL & Anti-Unfair Competition Law \\
\hline CCDI & Central Commission for Discipline Inspection \\
\hline CCP & Chinese Communist Party \\
\hline CEO & Chief Executive Officer \\
\hline CPI & Corruption Perception Index \\
\hline DOJ & Deferred Prosecution Agreement \\
\hline DPA & Foreign Corrupt Practices Act \\
\hline FCPA & GlaxoSmithKline \\
\hline GSK & U.S.-China Joint Liaison Group on Law Enforcement Cooperation \\
\hline JLG & Multinational Company \\
\hline MNC & Nonprosecution Agreement \\
\hline NPA & Organization for Economic Cooperation and Development \\
\hline OECD & Securities Exchange Commission \\
\hline SEC & Pepublic of China \\
\hline
\end{tabular}




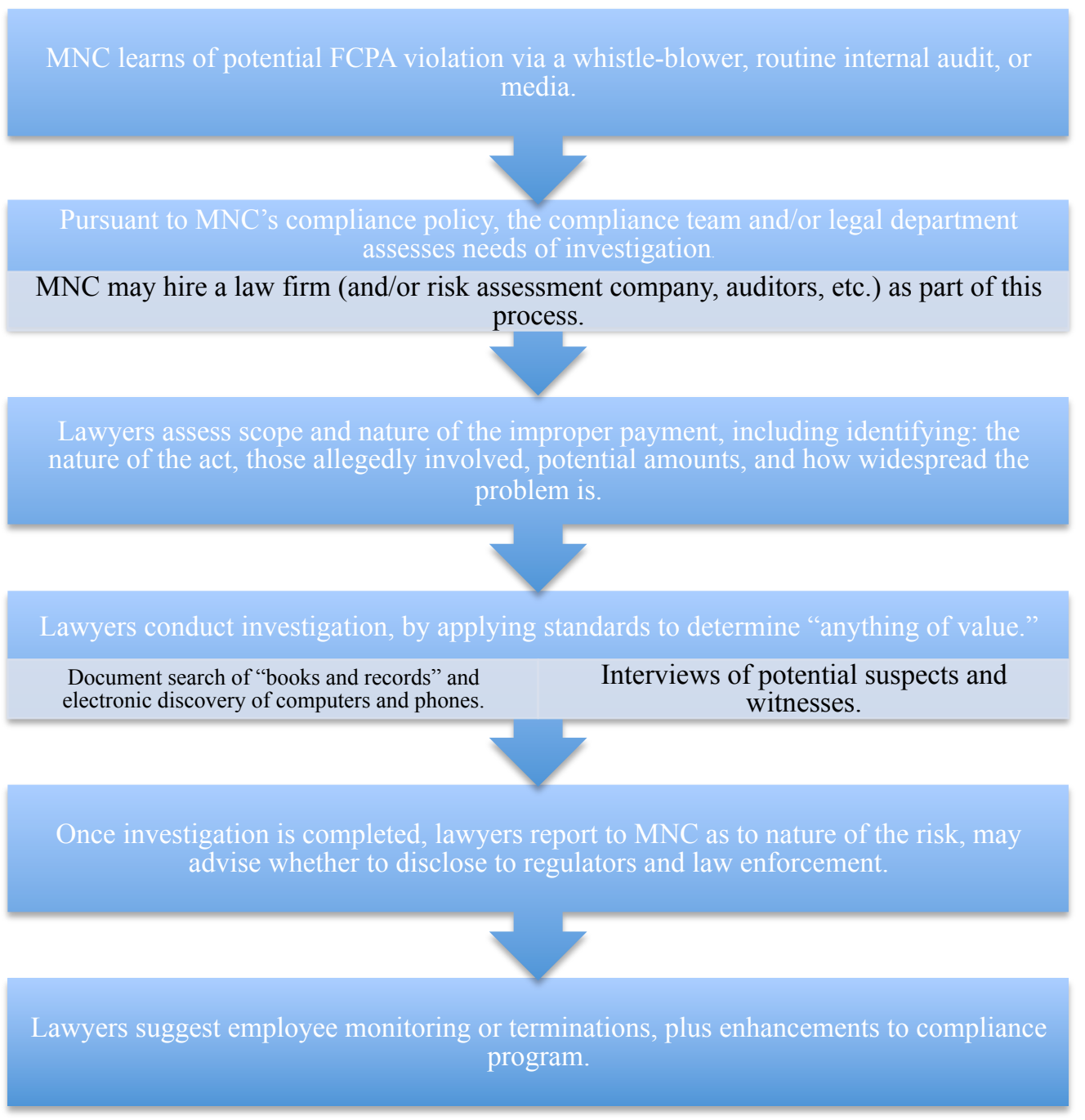

\section{Figure 1. The Process of Internal Investigations.}

\section{Appendix 1. DOJ Enforcement Actions, 2008-2016.}

\begin{tabular}{|c|c|c|c|}
\hline Year & $\begin{array}{c}\text { No. of } \\
\text { Actions }\end{array}$ & $\begin{array}{c}\text { Actions } \\
\text { with PRC } \\
\text { Nexus } \\
\end{array}$ & Description \\
\hline 2016 & 17 & 4 & $\begin{array}{l}\text { - General Cable Corporation paid } \$ 20 \text { million to resolve an } \\
\text { investigation into improper payments. } \\
\text { David Ng and Jeff C. Yin bribed ambassadors to the United Nations } \\
\text { to promote the interests of their real estate company in Macau. (The } \\
\text { resolution of this case is pending.) } \\
\text { JPMorgan Securities (Asia Pacific) Ltd. paid } \$ 72 \text { million for giving } \\
\text { jobs to relatives and friends of Chinese officials. } \\
\text { Parametric Technology (Shanghai) Software Co. Ltd. and Parametric } \\
\text { (Hong Kong) Ltd. signed an NPA for } \$ 14.5 \text { million for recreational } \\
\text { travel to the United States by PRC officials. }\end{array}$ \\
\hline
\end{tabular}


DRAFT

\begin{tabular}{|c|c|c|c|}
\hline 2015 & 15 & 0 & \\
\hline 2014 & 21 & 1 & $\begin{array}{l}\text { - Avon Products (China) Co. Ltd. paid } \$ 67.6 \text { million in criminal } \\
\text { penalties. See parallel SEC settlement. }\end{array}$ \\
\hline 2013 & 23 & 2 & $\begin{array}{l}\text { - Diebold Inc. paid \$25.2 million in criminal penalties for bribing PRC } \\
\text { officials. } \\
\text { Alain Riedo, vice president of Maxwell S.A. was indicted for bribing } \\
\text { PRC officials. See } 2011 \text { Maxwell settlement. }\end{array}$ \\
\hline 2012 & 13 & 3 & $\begin{array}{l}\text { - Nordham Group Inc. paid \$2 million for bribing PRC officials. } \\
\text { Biomet agreed to pay \$17.2 million for bribes in Latin America and } \\
\text { China. } \\
\text { Garth Peterson, a managing director of Morgan Stanley's real estate } \\
\text { business in China, served nine months in prison for unlawful benefits } \\
\text { in exchange for business PRC officials provided. }\end{array}$ \\
\hline 2011 & 9 & 1 & $\begin{array}{l}\text { Maxwell Technologies Inc. signed a DPA to pay } \$ 8 \text { million in } \\
\text { criminal penalties and to disgorge } \$ 13.6 \text { million in unlawful benefits. }\end{array}$ \\
\hline 2010 & 34 & 3 & $\begin{array}{l}\text { RAE Systems signed an NPA to pay } \$ 1.7 \text { million in criminal fines for } \\
\text { providing kickbacks and commissions to PRC officials. } \\
\text { Daimler AG signed a DPA to pay } \$ 93.6 \text { million in criminal fines for } \\
\text { paying bribes to officials in a number of foreign countries, including } \\
\text { China. } \\
\text { - DaimlerChrysler China Ltd. signed a separate DPA. }\end{array}$ \\
\hline 2009 & 43 & 9 & $\begin{array}{l}\text { - Control Components Inc. paid an } \$ 18.2 \text { million criminal fine as part } \\
\text { of settlement for } 200 \text { unlawful payments in } 30 \text { countries, including } \\
\text { China. } \\
\text { - Eight individuals were also separately charged as part of the Control } \\
\text { Components Inc. settlement. }\end{array}$ \\
\hline 2008 & 27 & 5 & $\begin{array}{l}\text { Mario Covino, a former executive of Control Components Inc., } \\
\text { served three years of probation and paid } \$ 7,500 \text {. } \\
\text { Siemens AG, agreed to five years' probation plus } \$ 448.5 \text { million in } \\
\text { criminal fines. See parallel SEC settlement. } \\
\text { Shu Quan-Sheng, a physicist, bribed PRC officials; as a result, he } \\
\text { served five months in prison and was supervised for two years. } \\
\text { Faro Technologies, Inc. signed an NPA to pay } \$ 1.1 \text { million for } \\
\text { corrupt payments to PRC officials. } \\
\text { AGA Medical Corp. signed a DPA to pay } \$ 2 \text { million for corrupt } \\
\text { payments to PRC doctors. }\end{array}$ \\
\hline TOTAL & 201 & $28(14 \%)$ & $\$ 804.2$ million \\
\hline
\end{tabular}

\section{Appendix 2. SEC Enforcement Actions, 2008-2016.}

\begin{tabular}{|c|c|c|c|}
\hline Year & $\begin{array}{c}\text { No. of } \\
\text { Actions }\end{array}$ & $\begin{array}{c}\text { Actions } \\
\text { with } \\
\text { PRC } \\
\text { Nexus }\end{array}$ & Description \\
\hline 2016 & 23 & 13 & $\begin{array}{l}\text { - JPMorgan paid a } \$ 264 \text { million fine for its "Sons and Daughters" } \\
\text { program for hiring children of officials in China and elsewhere in } \\
\text { Asia. } \\
\text { - GlaxoSmithKline agreed to pay } \$ 20 \text { million as a penalty for its China- } \\
\text { subsidiary's payments to hospitals to facilitate sales. } \\
\text { - } \mathrm{Nu} \text { Skin Enterprises paid } \$ 765,000 \text { for an improper payment to a }\end{array}$ \\
\hline
\end{tabular}




\begin{tabular}{|c|c|c|c|}
\hline & & & $\begin{array}{l}\text { charity tied to a CCP official. } \\
\text { Jun Ping Zhang, former CEO of Harris Corporation's subsidiary in } \\
\text { China, paid } \$ 46,000 \text { for facilitating a bribery scheme to pay illegal } \\
\text { gifts to Chinese officials. } \\
\text { AstraZeneca paid } \$ 5 \text { million to settle charges that it made improper } \\
\text { payments in China. } \\
\text { Johnson Controls paid } \$ 14 \text { million to settle charges that its Chinese } \\
\text { subsidiary used sham vendors to make improper payments. } \\
\text { - Akaimi Technologies agreed to sign an NPA to pay } \$ 652,452 \text { and } \\
\text { disgorge } \$ 19,433 \text { in interest for improper payments to PRC officials. } \\
\text { - Nortek Inc. signed an NPA to pay } \$ 291,403 \text { and disgorge } \$ 30,655 \text { in } \\
\text { interest. } \\
\text { - Las Vegas Sands agreed to pay } \$ 9 \text { million to settle charges that it } \\
\text { failed to document consultant facilitation fees in China and Macau. } \\
\text { - Novortis AG paid } \$ 25 \text { million to settle charges that its China } \\
\text { subsidiaries engaged in pay-to-prescribe schemes to increase sales. } \\
\text { Qualcomm Incorporated paid } \$ 7.5 \text { million to settle charges that it } \\
\text { hired the son of a Chinese official to procure contracts. } \\
\text { PTC paid } \$ 28 \text { million to settle charges that it bribed Chinese officials. } \\
\text { - SciClone Pharmaceutical paid } \$ 12 \text { million to settle charges that its } \\
\text { employees made improper payments to health care professionals. }\end{array}$ \\
\hline 2015 & 9 & 2 & $\begin{array}{l}\text { Bristol-Myers Squibb agreed to pay more than } \$ 14 \text { million to settle } \\
\text { charges that its employees of its China-based joint venture made } \\
\text { improper payments to obtain sales. } \\
\text { Mead Johnson Nutrition agreed to pay } \$ 12 \text { million to settle charges } \\
\text { that its employees made improper payments. }\end{array}$ \\
\hline 2014 & 8 & 2 & $\begin{array}{l}\text { Avon Products Inc. paid } \$ 135 \text { million to settle charges that it failed to } \\
\text { put in place controls to prevent gifts to Chinese officials. } \\
\text { Bruker Corporation paid } \$ 2.4 \text { million to settle charges that it made } \\
\text { improper payments to Chinese officials. }\end{array}$ \\
\hline 2013 & 8 & 0 & \\
\hline 2012 & 10 & 4 & $\begin{array}{l}\text { Eli Lilly and Co. paid } \$ 29 \text { million to settle charges that its employees } \\
\text { made improper payments to officials in a number of countries, } \\
\text { including China. } \\
\text { Pfizer agreed to pay } \$ 45 \text { million to settle charges that its employees } \\
\text { made improper payments to officials in a number of countries, } \\
\text { including China. } \\
\text { Garth Peterson was permanently barred from the securities industry } \\
\text { and paid } \$ 250,000 \text { in disgorgement and relinquished } \$ 3.4 \text { million } \\
\text { interest in real estate. } \\
\text { Biomet paid } \$ 22 \text { million to settle charges that its employees bribed } \\
\text { doctors to sell its products in a number of countries, including China. }\end{array}$ \\
\hline 2011 & 15 & 4 & $\begin{array}{l}\text { - Watts Water Technologies paid } \$ 200,000 \text { in civil penalties and } \\
\$ 820,791 \text { disgorged } \$ 2,755,815 \text { in prejudgment interest, for improper } \\
\text { payments disguised as sales commissions. Former vice president } \\
\text { Leesen Chang paid } \$ 25,000 \text { in civil fines. } \\
\text { Rockwell Automation, Inc. paid } \$ 400,000 \text { in civil penalties and } \\
\text { disgorged } \$ 1,771,000 \text { for improper payments to Chinese officials. } \\
\text { - IBM paid } \$ 10 \text { million for improper payments to officials in China and } \\
\text { South Korea. } \\
\text { Maxwell Technologies paid } \$ 6.3 \text { million for making repeated bribes } \\
\text { to Chinese officials. }\end{array}$ \\
\hline 2010 & 15 & 2 & $\begin{array}{l}\text { RAE Systems paid } \$ 1.25 \text { million to settle charges that its employees } \\
\text { made improper payments to Chinese officials. }\end{array}$ \\
\hline
\end{tabular}




\begin{tabular}{|c|c|c|c|}
\hline & & & $\begin{array}{l}\text { - Veraz Networks paid } \$ 300,000 \text { to settle charges that it made improper } \\
\text { payments to Chinese officials. }\end{array}$ \\
\hline 2009 & 12 & 4 & $\begin{array}{l}\text { - UTStarcom Inc. paid } \$ 1.5 \text { million to settle charges that it paid for } \\
\text { hundreds of overseas trips for Chinese officials. } \\
\text { Oscar Meza, formerly the director of sales for Faro Technologies, } \\
\text { Inc., paid } \$ 30,000 \text { in civil penalties and disgorged } \$ 26,707 \text { for bribing } \\
\text { Chinese officials. } \\
\text { Avery Dennison Corp. paid } \$ 200,000 \text { in civil penalties and disgorged } \\
\$ 273,213 \text { and } \$ 45,257 \text { in prejudgment interest for improper payments } \\
\text { to Chinese officials. } \\
\text { ITT Corp. paid } \$ 250,000 \text { in civil fines and disgorged } \$ 1,041,112 \text { with } \\
\$ 387,538 \text { in prejudgment fines for making improper payments to } \\
\text { Chinese officials. }\end{array}$ \\
\hline 2008 & 10 & 2 & $\begin{array}{l}\text { - Siemens AG disgorged } \$ 350 \text { million for paying bribes to officials in a } \\
\text { number of countries including China. } \\
\text { Faro Technologies, Inc. disgorged } \$ 1,411,306 \text { and paid } \$ 439,637 \text { in } \\
\text { prejudgment interest to settle charges that it made improper payments } \\
\text { to officials in China. }\end{array}$ \\
\hline TOTAL & 110 & $33(30 \%)$ & $\$ 1.02$ billion \\
\hline
\end{tabular}

